\title{
FRAMING CONTESTS: STRATEGY MAKING UNDER UNCERTAINTY
}

\author{
Sarah Kaplan \\ University of Pennsylvania, Wharton School \\ 3620 Locust Walk, Suite 2019 \\ Philadelphia, PA 19104-6370 \\ 215-898-6377 \\ slkaplan@wharton.upenn.edu
}

Forthcoming in Organization Science

This research was supported by the MIT Communications Technology Roadmap project and has benefited from the comments of many individuals and audiences, primary among them: Daniel Beunza, Tina Dacin, Mauro Guillén, Heather Haveman, Rebecca Henderson, Anne Huff, Kate Kellogg, Katherine Klein, Dan Levinthal, Michael Lounsbury, Wanda Orlikowski, Leslie Perlow, Patrick Regnér, Scott Stern,

Gabriel Szulanski, Andrew van de Ven, Marc Ventresca, Mark Zbaracki, Ezra Zuckerman, three anonymous reviewers, the HBS Qualitative and Inductive Methods research group, the

slump_management research group, and seminar participants at the Prince Bertil Symposium, the BYU/University of Utah Winter Strategy Conference, Harvard Business School, INSEAD, London Business School, MIT, New York University, University of California, Irvine, University of Minnesota, Universitat Pompeu Fabra, University of Toronto, and the Wharton School. The usual disclaimers apply. 


\title{
FRAMING CONTESTS: STRATEGY MAKING UNDER UNCERTAINTY
}

\author{
Abstract: I develop a model of framing contests to elucidate how cognitive frames influence \\ organizational strategy making. Using ethnographic techniques to study the day-to-day practices of \\ strategy making in one firm, I examine the ways actors attempted to transform their own cognitive frames \\ of a situation into predominant frames through a series of interactions. Frames are the means by which \\ managers make sense of ambiguous information from their environments. Actors each had cognitive \\ frames about the direction the market was taking and about what kinds of solutions would be appropriate. \\ Where frames about a strategic choice were not congruent, actors engaged in highly political framing \\ practices to make their frames resonate and to mobilize action in their favor. Those actors who most \\ skillfully engaged in these practices shaped the frame which prevailed in the organization. This framing \\ perspective suggests that frames are not only instrumental tools for the ex post justification of actions \\ taken through power but rather are an ex ante part of the political process that produces decisions. \\ Uncertainty opens up the possibility for new actors to gain power, and contesting frames is a way of \\ changing the power structures in the organization. A principal contribution of the framing contests model \\ is to locate a middle ground between cognitive and political models of strategy making, one in which \\ frames are both constraints and resources and outcomes can be shaped by purposeful action and \\ interaction to make meaning.
}

Key words: frames, cognition, strategy making, social movements, politics, strategy as practice 
It is well established that firms have difficulties managing changes in their environment, be they technical innovations (Henderson and Clark 1990), regulatory changes (Smith and Grimm 1987) or market crises (Haveman 1992). While some organizations are able to adapt, many are subject to strong inertial forces. As Knight (1921/1965) has suggested, it is not these environmental changes per se that make them hard to handle but rather managers' associated inability to assess what the changes mean. Such turbulence creates a challenge for strategy making, an activity that requires managers to match strategic choices to their understanding of the external environment (Bower 1970). Where the basic meaning of the situation is up for grabs, information from the environment cannot be comprehended as a set of easily recognizable signals.

Research in managerial cognition has suggested that cognitive frames are the means by which managers sort through these ambiguities (c.f., Walsh 1995, for a review). This research is based in a view that strategic action is influenced by how managers notice and interpret change and translate those perspectives into strategic choices (Daft and Weick 1984). An important agenda for this field is to understand better how cognitive frames affect outcomes (Fiol and Huff 1992; Huff 1990; Porac and Thomas 2002). Several theoretical models outline how interpretive processes might influence strategy (Kiesler and Sproull 1982; Ocasio 1997), and some empirical work has shown that managers' frames shape interpretations of the environment and subsequent strategic choices during turbulent times (Barr 1998; Barr, Stimpert and Huff 1992; Kaplan Forthcoming; Tripsas and Gavetti 2000). We know less, however, about the underlying mechanisms within the strategy-making process that produce this connection. In particular, because such flux makes multiple cognitive frames possible, any model of action in these contexts would require an accounting for how certain frames come to predominate over others. Managerial cognition scholars have responded to this challenge by calling for a move beyond purely content issues (Bogner and Barr 2000; Elsbach, Barr and Hargadon 2005; Lant 2002): they have suggested that an understanding of cognitive mechanisms in such processes as strategy making requires acknowledgement of the situated and interactive nature of cognition.

Studies exploring organizational strategy-making processes have, however, mostly produced political models in which the pursuit of interests by individuals or groups is the mechanism affecting outcomes (Bower 1970; Bower and Doz 1979; Burgelman 1994; Eisenhardt and Bourgeois 1988; Pettigrew 
1973). Cognitive effects have largely been left to the side. These models suggest that actors, responding to their own incentives, shape agendas and control information flows in order to steer strategic choices in a preferred direction. Though some acknowledge the influence of worldviews (Pettigrew 1973) or of biases in perception (Bower 1970), scholarship in this arena has not explicitly theorized about how cognition relates to political models of strategic choice. Similarly, managerial cognition research has mainly bracketed political action (Weick, Sutcliffe and Obstfeld 2005). The link between cognition and politics in strategy-making research remains under-developed. The study reported here explores this connection by examining the political processes by which one frame rather than another comes to predominate and the ways these frames influence strategy making. A primary contribution of this paper is to portray framing in strategy making as highly contested and tightly intertwined with the political pursuit of interests.

To guide my analysis, I draw on social movement research on framing which offers one way for thinking about the integration of cognition and politics and brings into focus the actions taken to shape the frames of others. This work is based on Goffman's (1974) articulation of frames as guides to interpretation which are constructed through interaction. Frames shape how actors recognize what is going on, and framing is "an active processual phenomenon that implies agency and contention at the level of reality construction" (Benford and Snow 2000: 613). According to this perspective, social movement actors engage in framing activities in an attempt to mobilize others around a particular point of view. While this research has primarily been conducted at the field level, I use these theories to illuminate the dynamics of strategy making within an organization in order to reveal the micro-mechanisms by which frames and politics interrelate.

To investigate the organizational processes that connect framing to outcomes, I used ethnographic techniques to study strategy making at CommCorp (a pseudonym), an established firm in the communications technology industry. The research was conducted during a period of industry upheaval when the telecommunications "bubble" burst. Studying an organization during such turbulence uncovered features that would be buried beneath the surface during more stable times (Meyer, Gaba and Colwell 2005). Specifically, I adopted a practice approach (Jarzabkowski 2005; Orlikowski 2000) to examine the day-to-day activities of managers in the unfolding of two strategic initiatives which represented varied responses to the crash. 
This focus on practice led to theoretical insights about the nature of frames and the organizational dynamics through which they shape strategic choices, a model which I call "framing contests."1 This model elucidates how actors attempt to transform their own cognitive frames into the organization's predominant collective frames through their daily interactions. Where frames about a decision are not congruent, actors engage in framing practices in an attempt to make their frame resonate and mobilize action in their favor. These practices embody more or less skillful efforts to establish the legitimacy of their frames and of themselves as claimsmakers or to realign frames in order to influence how others see issues. These framing practices define what is at stake and, thus, are a means of transforming actors' interests. If framing activities are successful, one particular frame will come to predominate as a guide to actors' positions regarding a strategic choice. If these efforts are not successful, frame divergence can defer decisions. How these contests play out shapes the degree of continuity or change created through the strategy-making process.

This view is a significant departure from the way cognition has traditionally been construed in the managerial cognition literature. Instead of a static sense of cognition in which actors are often constrained by “psychic prisons" (Bolman and Deal 1991/2003), the framing contests model represents cognition as a dynamic, purposive and politically-charged process of meaning construction. The fact that frames can be changed makes them a potential locus of contestation. Yet, it is also clear that individuals have particular cognitive dispositions and cannot deploy frames in a purely instrumental fashion. Framing practices are not simply political acts of issue selling (Dutton and Ashford 1993) or impression management (Elsbach and Sutton 1992), but are constrained by the cognitive frames of the individuals engaged in them. Thus, the framing contests model finds a middle ground between cognitive and political models of strategy making, one in which frames are both constraints and resources, and outcomes are shaped by purposeful action and interaction. The focal point of the political process is the collective effort of meaning making, such that the pursuit of interests can only be understood alongside the frames actors use to interpret those interests. Making strategy under uncertainty can therefore be comprehended as a product of contests over which frame

\footnotetext{
${ }^{1}$ This term builds on research in the communications and media studies field on how grassroots political organizations use "frame contests" to shape media coverage of their causes, in which the "news frame" of journalists not only interprets the events but creates them (See in particular, Ryan 1991, who coined the term).
} 
should guide the understanding of an ambiguous environment and of choices about how to respond to it.

The remainder of the paper is organized in five sections. To anchor the discussion of framing, the first section briefly reviews perspectives on strategy making, frames and politics. The next section outlines the ethnographic techniques I used for my grounded theory building and describes the two strategic initiatives studied at CommCorp. I then analyze the function that highly political contests among frames played in shaping the strategic choices made over the course of these initiatives. The discussion section reflects on the implications of a framing contests model for research on managerial cognition, strategy making and organizational inertia and adaptation during periods of uncertainty.

\section{STRATEGY MAKING, FRAMES AND POLITICS}

Early models of policy making, such as multiple rationalities (Diesing 1962), muddling through (Lindblom 1965), the clinical approach (Archibald 1970) or garbage can (Cohen, March and Olsen 1972), offered quite complex views of strategy. All admitted that power and politicking were parts of the policy-making process, and all used bounded rationality (Simon 1947) to explain decision outcomes. This research focused, for the most part, on how problems and solutions were matched in light of the cognitive limits of managers. While these foundational studies highlighted the importance of both cognitive and political forces in shaping strategic choices, they left open questions about the sources of interpretations, the process by which certain meanings came to prevail in the organization and the ways in which politics played out over time. They inspired a long stream of scholarship in strategic management which has sought to unpack these effects.

Initially, political models of the strategy process gained the most traction. Allison (1971: 171) suggested that the strategy-making process was one in which "each player pulls and hauls with the power at his discretion for outcomes that will advance his conception of...interests." In the organizational domain, Bower (1970) and Burgelman (1983) showed that the political process of giving projects impetus through the organization determined where resources get allocated, and Pettigrew (1973) demonstrated that power mobilization around particular issues influenced the direction of strategy. While the degree of politicking (such as agenda control or coalition formation) differed in these analyses (Eisenhardt and Bourgeois 1988), the underlying mechanism driving outcomes was actors' pursuit of their interests. However, by 
foregrounding political explanations, this work bracketed cognitive dynamics (Eisenhardt and Zbaracki 1992). While some scholars of strategy processes mentioned the role of the perception of interests (Bower and Doz 1979), worldviews (Pettigrew 1973), or biases in perception (Bower 1970), such cognitive factors were not central to their explanations of strategic outcomes.

Yet, especially during periods of high uncertainty, it would seem that cognitive frames should be central to strategy-making processes as actors attempt to make sense of ambiguous signals from the environment. With this in mind, a separate stream of research in strategic management introduced cognitively-based models to the study of strategy (Huff 1990). These managerial cognition scholars argued that managers need to interpret their situations in order to make strategic choices and act (Daft and Weick 1984). This work focused on establishing the presence of cognitive frames and their association with strategic outcomes. More to the point of this paper, research in this tradition has suggested that strategic change involves cognitive reorientations (Barr 1998; Barr et al. 1992; Kaplan, Murray and Henderson 2003; Szulanski, Doz and Ovetzky 2004). The underlying model is one in which cognitive frames direct managerial attention and thus influence firm response to changing circumstances. This work has isolated cognitive frames from other effects in order to study their influence on strategic outcomes. While recent firm-level quantitative analyses suggests that frames and interests are intertwined in their effect on strategy in periods of flux (Kaplan, Forthcoming), we know less about how these dynamics play out inside the organization. Just as political models have tended to neglect cognitive mechanisms, managerial cognition research has not often considered the interplay with political action (Weick et al. 2005). This seems problematic for understanding strategy making in turbulent settings because uncertainty can result in myriad interpretations about what is going on and what should be done (Louis 1980). The existence of these multiple, often conflicting, views opens up the possibility for actors' agentic engagement in contests to control which meanings become legitimated (Sewell 1992). Such political action is about the pursuit of interests, but actors' motives depend on the frame applied to the situation and, reciprocally, interests help select which frame will be applied (Goffman 1974). These settings force us to consider the plurality of views that emerge (Glynn, Barr and Dacin 2000), which means that it is important to ask not only how frames shape strategic choices 
but also how one frame comes to predominate over others. An answer to these questions will require the development of more explicit links between cognition and politics in a theory of strategy making.

Scholarship in social movements is one place where this integration of cognition and politics has been taking place, though at a different level of analysis and not in the domain of firm strategy making (for useful summaries, see Benford and Snow 2000; and, Snow, Soule and Kriesi 2004). Growing out of the symbolic interactionist tradition (Fine 1993) and in particular from Goffman's (1974) frame analysis, social movements research suggests that the framing practices of activists can affect which frames prevail in societal discourse and in setting policy agendas. These theories call attention to the purposeful efforts that skilled actors take to shape the frames of others and how those interactions can lead to coalition formation and conflict. When changes in the environment create political opportunities for action, proponents and opponents of certain frames attempt to mobilize others by engaging in framing activities (Gamson and Meyer 1996; Snow, Rochford Jr., Worden and Benford 1986). Benford and Snow (2000) identify legitimacy claims and frame realignment as two such framing practices. Legitimacy battles occur as actors work to establish the empirical credibility of their frame or their authority as claimsmakers. Frame realignment involves bridging related but unconnected frames, amplifying latent frames, extending a frame to new issues or transforming frames to align with new circumstances (Snow et al. 1986). In the deployment of these practices, coalitions are built around powerful frames (ones which resonate broadly), and powerful coalitions can shape policy.

Increasingly, institutional and organizational theorists are using social movement theories to explain industry phenomena (Davis, McAdam, Scott and Zald 2005). They have argued that collective action may be most evident in periods of transformation (Fligstein 1996) when actors construct legitimating accounts in order to shape the direction of change (Creed, Scully and Austin 2002). Institutional research has suggested that social movement organizations can act entrepreneurially to shape market outcomes across firms by gaining political support for a new frame (Lounsbury and Rao 2004; Lounsbury, Ventresca and Hirsch 2003; Rao 1998). Scholars have long suspected that social movements might also emerge inside organizations (Zald and Berger 1978), but less is known about how this might play out.

While social movement research provides a more explicit integration of cognition and politics in 
understanding policy choices, these models have been criticized for their over-emphasis on framing as composed of rhetorical or influence techniques alone (Fine 1993; Steinberg 1999). Indeed, from the perspective of the management literature, one could read the framing activities in social movements as issue selling (Dutton and Ashford 1993) or impression management (Elsbach and Sutton 1992) in which actors' interests are objectively given and guide the instrumental deployment of frames. But, if we turn back to Goffman's (1974: 21) original conceptualization of frames, he argues that they are not simply tools to deploy but rather "schemata of interpretation" which allow actors to make sense of ambiguous and varied signals. That is to say, frames shape how individual actors see the world and perceive their own interests. Actors make choices and act from within that understanding. By corollary, framing also allows people to suggest what is going on to others. This process is not necessarily seamless and inevitable. Goffman notes that people have multiple frames from which they can draw in any one moment. He leads us to a more symbolic interactionist view of frames than that taken up by social movement research (Fine 1993; Gamson 1985). From this viewpoint, it is in interaction with others that the meaningfulness for the individual is established and collective meaning is negotiated. Giddens (1984), who was very much inspired by Goffman's work, suggests that power is enacted in these interactions (see also, Bourdieu 1977). The "powerful" do not always get their way because other actors' engagement in framing practices enables coalition building.

Applying these views to an analysis of organizational strategy making shifts the analytical focus from the firm as a whole to the internal wrangling taking place within a project and from a particular class of executives normally charged with making strategy to the full set of actors involved in shaping a decision. Most appealingly for this study, these theories give us a means to marry political and cognitive stories about how strategic choices get made and serve as a basis for the framing contests model developed in this paper.

\section{METHODS AND DATA}

An important implication of using Goffman (1974) as a foundation for this study is the view that organizations can (and should) be understood from the bottom up through the day-to-day practices and interactions of actors. Ethnographic techniques are prescribed as a means for understanding the "interaction order" in the organization (Goffman 1983). This is consistent with recent moves within the strategic 
management field to take a practice approach to studying strategy (Jarzabkowski 2005). This approach conceives of actors as knowledgeable and purposeful and yet always acting in situated performances (Feldman 2003; Orlikowski 2000). Such performances construct organizational strategies of action within which particular strategic choices make sense. This study was designed with these principles in mind.

\section{Research setting}

The research was based on observations of strategy making in the Advanced Technologies Group (ATG) of CommCorp, a multidivisional manufacturer of communications technologies broadly representative of large incumbent firms in the industry. ${ }^{2}$ As with other firms in the industry, CommCorp had experienced tremendous growth in the 1990s as it pursued a variety of products to support the rapidly growing fiber-optic network. The bursting of the telecommunications "bubble" and collapse of the fiber-optic market in 20012002 called into question a technology strategy based almost entirely on optics and resulted in significant layoffs and budget cuts. Yet, technical change, even in fiber optics, continued at a rapid pace. This high velocity environment (Bourgeois and Eisenhardt 1988) is suited to research on strategy making because the extremity of the situation heightened the visibility of actors' cognitive frames. In such circumstances, cognitive frames are less likely to be givens that are embedded in routines and indivisible from interests (Bogner and Barr 2000; Kaplan and Henderson 2005), and thus their separate effects can be examined. In addition, a deep exploration within one firm is justified when the goal is to reveal processes and micromechanisms (Dougherty 1992b; Pettigrew 1987; Strauss and Corbin 1997).

ATG was a corporate R\&D group charged with setting the technical direction of the corporation.

This involved not just developing technologies but also making sure that these technologies had relevance to the market and to internal customers (the business units). As a result, while ATG was mainly composed of technical personnel, it also included economic analysts and marketing staff who helped develop business cases for each initiative. All investment decisions in ATG were subject to a fairly democratic decision process in which projects were screened by a Steering Committee made up of technical personnel before they

\footnotetext{
${ }^{2}$ The names of the company, projects and individuals are disguised to protect confidentiality.
} 
advanced to the Review Board (ATG's senior team) that had responsibility for approving projects.

This paper reports on the unfolding of two technology strategy initiatives within the ATG organization at CommCorp - the Last Mile and Multiservice projects - each involving three resource allocation decisions. Each represented strategic responses to the crash in the market for optical technologies. These initiatives were identified after a series of unstructured interviews with ATG's senior management team, other managers and engineers. Each was in a critical technology arena and in its early stages as I began my field work. The two initiatives were chosen for their contrasts: they were based on different technologies, were led by different managers, and followed different decision trajectories. This variation assures that themes identified in my analysis are reflective of underlying structures rather than of superficial commonalities. I also collected detailed data on three other projects and general information on many others (there were 40 projects "on the books" during the time of my observations). These data validated that the focal cases were representative of other projects in the portfolio and helped calibrate the findings.

\section{Data collection}

The goal of this ethnographic research was to uncover "the soft underbelly" (Latour and Woolgar 1979) of strategy making by looking at what actors did individually and collectively to construct strategic choices. I relied heavily on observations of everyday activities, using other sources of data - such as interviews and documents - to amplify and verify my insights. The core of the data collection occurred over 8 months of field work from April to December 2002. In this period, I observed activities associated with the two focal initiatives, conducted 80 formal, unstructured interviews, observed 33 meetings (from 2 hours to 2 days long), and collected documentation for each project (e.g., e-mails, spreadsheets, PowerPoint documents, agendas and meeting minutes). This took place in the course of seven (3-5 day) site visits to the headquarters location, five (1 day) visits to a branch location, and daily telephone meetings and interviews when I was not on site. Due to the geographic dispersion of the teams, most meetings were conducted using conference calls in which I regularly participated, and most communications occurred in emails. Thus, being "in the field" took on an atypical meaning as many contacts were conducted electronically (Hine 2000). Interviews were recorded and transcribed. I also made notes during each interview and wrote these up daily. 


\section{Analytical approach}

My analytical approach was open-ended and inductive (Strauss and Corbin 1997) but driven by a broad interest in how managers made decisions about investments during periods of uncertainty and specifically focused on understanding the generation of meaning by the actors within the organization. As such, the unit of observation was the initiative while the unit of comparison in my analysis was the strategic decision.

Using the decision as a focal point for understanding management activity goes back at least to Barnard (1938). In the context of strategy, Allison (1971) famously used the decision as an entrée into understanding policy in the Cuban Missile Crisis, and strategic management scholars have gained some traction in studying decisions as well (Bourgeois and Eisenhardt 1988; Papadakis, Lioukas and Chambers 1998). Such decisions are not just occasions for deciding what to do next but are more broadly about setting the strategic direction of the organization (March 1994). It was not possible to identify these decisions ex ante. At the starting point of the research, the only evident subject of study was the initiative. Therefore, the research proceeded by selecting initiatives to scrutinize and then observing decisions as they emerged. I studied the myriad decisions made each day regarding, for example, which analyses to conduct, which data to use or whom to include in a meeting. Consistent with my emphasis on strategy making specifically, the analysis focused on a comparison of those pivotal decisions with long term implications in which resource allocations were at stake (Child 1972). These included both explicit, formal decisions as well as "deferred decisions" (Tversky and Shafir 1992) where actors decided not to decide. These latter represent unresolved activities. As Greenwood and Hinings (1988) suggest, theorizing about organizational outcomes must encompass such deferred activities to avoid any bias from looking only at successful decision outcomes. My investigation conformed to the principles of grounded theory from cases (Dougherty 2002; Eisenhardt 1989a; Yin 1984). Data analysis began as the field work began: I wrote commentaries on each interview or meeting and composed weekly memos about emerging themes. In a first stage of analysis, I used information from my field notes, transcripts and archival materials to construct time lines for each initiative covering the events that took place and the different interpretations of those events by the key players in each project. This level of detail allowed me to locate the turning points in projects and identify the means by 
which they were achieved. Based on the insights generated from the chronologies and the weekly memos, I built an initial list of themes and codes for analyzing the data - an approach to content analysis where the themes are suggested from the data rather than being imposed from the outside (Agar 1980). I coded each element of the chronologies, adding new codes as they emerged from multiple readings of the data.

In a second stage, I explored how frames shaped each of the six strategic choices through a frame analysis (Goffman 1974; Johnston 1995). Frame analysis involves understanding how actors deploy frames both to make sense of a decision context and to shape outcomes (Creed, Langstraat and Scully 2002). I identified frames from statements made in interviews, interactions and documents. Following research on categories of frames, these were organized into diagnostic (assessment of the problem) and prognostic (assessment of the solution) aspects of frames (Benford and Snow 2000; Campbell 2005). This is consistent with a focus on the strategic choice, as decisions involve matching problems and solutions. For each choice, I identified the cognitive frames of actors involved, noting the proponents and opponents at each point in time. As an example, Appendix 1 shows the evidence for the frames for one informant, Hermann Meier, in the Last Mile project. I then examined what, if any, actions actors took to get their own frames to predominate.

In line with ethnographic practice, I sought "breakdowns" (Agar 1986: 20) in my understanding both during the period of observations and after. For example, while I started the study focused mainly on cognition, it was the overwhelming presence of political action that led me to draw on social movements theories and ultimately to construct a political model of framing contests. I iterated between raw data, emerging themes and the related literature to settle on overarching concepts and their interrelationships. To assure validity, I searched for patterns by comparing across decisions to look for differences and understand why they occurred. After developing a preliminary model, I conducted a series of interviews with informants to validate the themes, revising further where new insights emerged.

\section{UNFOLDING OF STRATEGIC DECISIONS IN TWO INITIATIVES}

Observations of the Last Mile and Multiservice initiatives at CommCorp suggest that the direction strategic decisions should take was rarely clear. Frames about what was happening in the market and what should be done differed substantially across actors, and the resolution of these differences shaped the outcomes across a 
series of strategic choices. In this section, I trace the unfolding of these strategic choices. Of the six decisions studied here, five were highly contested and one was not, and two of the contested decisions led to unresolved activity and deferred decisions. Table 1 summarizes these patterns, shows the salient diagnostic and prognostic aspects of frames for both proponents and opponents and demonstrates the shifts in coalitions for and against each initiative across the different stages of the decision-making process.

-- Insert Table 1 about here --

Last Mile: should we invest in optical access technologies? The Last Mile project was initially proposed by Hugh Collins, a senior scientist in ATG, to expand optical access technologies. As optical technologies spread throughout the communications system, the "last mile" was the least penetrated because the economics had not historically supported expansion. With the crash in the long-haul optical market, managers like Hugh perceived that a solution to the glut of bandwidth in the core was to install highbandwidth, fiber-based connections to the access points. The contests revolved around differences in frames about the future value of fiber-optics ("pro-optical" vs. "anti-optical"), the future level of demand ("market opportunity" vs. "market pessimism") and about the appropriateness of optical technologies (in particular the "OpAccess",3 technology that Hugh had previously prototyped) as a solution. The project proceeded through three hotly debated decisions. The first was an initial decision to kick off a " 100 day" study to scope out a major development project. The second decision was deferred as a result of Hugh's dramatic departure in the middle of a Review Board meeting. He left because he felt he could not counter the very strong efforts by opponents to halt the project. When Hugh and his successor as project leader, Hermann, reframed the solution as consistent with a "business unit focus," they were able to minimize the pressure from opponents and build a coalition of supporters. The final decision was to make a small investment to support a single product line rather than pursue the originally proposed major development project.

Multiservice: should we invest in developing an algorithm that bridges old and new network technologies? The market crash meant that telecommunications carriers' corporate customers could not

\footnotetext{
${ }^{3}$ For reasons of confidentiality, the nature of the technology is disguised.
} 
afford new technology investments, yet the carriers needed to continue to upgrade their networks. The Multiservice project was a bridge technology in the form of an algorithm that would allow carriers to provide multiple services to their business customers without requiring these capital-constrained enterprises to scrap legacy installed equipment. Developed initially by some mathematicians in Jack Stafford's group, the project started out as a technology looking for a business case. The contest in this project stemmed from different frames about the viability of this business case given its basis in optical technologies. The project proceeded through three different decision points. The first decision involved the development of the algorithm for a niche application. A marketing person (Tom Rentham) assigned to create a business case was unsuccessful in finding a rationale for the overall project, but did identify a small application while working with a product line manager in a business unit. This was easily approved by the Review Board with no opposition. At the second decision point, when Jack could not produce an adequate business case, the Steering Committee deferred a decision about investment in the larger project. Jack's view that new optical solutions were required to respond to the market threat did not resonate with people focused on short term business unit needs and convinced that optics no longer presented an opportunity. Frustrated by what he perceived to be his opponents' narrow-mindedness, Jack took the case directly to a customer who agreed to a trial. With the tacit support of his boss (Erik Helgesen), Jack staffed up a development effort that was much larger than the one originally proposed. The Review Board only formally ratified this third decision two months later.

In these two projects, we see how the ambiguities of the environment led to widely diverging frames about what was going on and what should be done. Actors attempted to shape how others perceived the situation and made strategic choices. I seek to explain these dynamics in the following sections.

\section{FRAMING CONTESTS}

The evidence from the stories of these two initiatives suggests that frames played a critical role in shaping the strategic choices made in CommCorp's Advanced Technology Group. This was not a predictable causal relationship but rather a dynamic and contested process of framing. Coalitions shifted over time as proponents and opponents worked to frame the initiative in a way that would resonate more broadly. Actors each had cognitive frames about the direction the market was taking and about what kinds of solutions would 
be appropriate. They then worked to get those frames to predominate as choices about investment were made. I describe the underlying mechanisms in a model of organizational framing contests (Figure 1). -- Insert Figure 1 here --

To start, certain cognitive frames were salient for each actor in the context of an initiative. Cognitive frames can be comprehended in Goffman's (1974: 21) sense of "schemata of interpretation" that allowed individuals to organize their understanding of the environment. Individuals had particular cognitive predispositions that influenced how they interpreted the information from the environment and subsequently what actions they took in their engagement with particular initiatives. To the extent that frames did not align, proponents and opponents of a project engaged in framing practices to make their cognitive frames resonate at the collective level and to mobilize action in favor of a desired decision outcome. These practices shaped and were shaped by the interests of different actors. Consistent with Bourdieu's (1977) and Giddens' (1984) conceptualization of power as enacted by skillful actors, at CommCorp power was not something that actors possessed but rather something that occurred in interaction through an actor's engagement in framing practices. By attempting to establish the legitimacy of a frame or of themselves as claimsmakers or by realigning the frames in play, actors sought to push the strategic choice in the direction of their own frames and interests. Yet, framing was not only an instrumental activity in which actors could simply select the most useful frame to support their own interests. Actors' cognitive predispositions defined the scope of action for their own framing practices. In this way, interests were not fixed but rather transformed as a result of framing practices such that new frames made others believe that the proposed solution was in their own interests.

If framing practices were successful, this process produced a predominant frame. This frame shaped how the problem and solution were defined and thus which strategic choice was made. Where no frame resonated enough to mobilize action around it, frames remained divergent, activities unresolved, and the decision deferred. Frames could only structure outcomes to the degree that they were shared and collectively enacted. Frames were thus both individual and social: the cognitive frames of individuals only shaped organizational action when they came to predominate through the group's processes at the time a decision was made. Predominant collective frames were not known a priori but rather emerged as products of 
interactions. Below, I explore in more detail the cognitive frames and their sources, the framing practices used to make a particular frame prevail and the intertwining of such practices with political action.

\section{Cognitive frames and their sources}

Cognitive frames were the lenses through which actors at CommCorp saw the environment. To illustrate how this worked, we can examine the case of Hugh Collins in the context of the Last Mile project. Hugh was an optical engineer and the holder of many critical patents upon which the fiber-optic network was based. He had worked at CommCorp for many years, exclusively in ATG's predecessor organization, "CommCorp Labs," which had historically given inventors quite a bit of free rein in their activities. As a result, Hugh saw the world through a "pro-optical" lens (as noted in Table 1). Despite the crash in the market, he continued to see optics as the technology that would drive the future of communications. Continued aggressive investment in optics would be necessary to turn the market around and position CommCorp as the future leader. This diagnostic frame led him to see the crash as a threat because it might cause the organization to cut back on investments. He also believed that the way to revive the market was to increase demand by giving end users access to high-bandwidth, optical connections. When people challenged his view, he spent considerable effort collecting data on the inadequacy of the existing copper infrastructure. Similarly, because Hugh had been involved in prior OpAccess prototype projects, his prognostic frame of the solution was to develop OpAccess and take it to market. As he noted, "It is natural to gravitate to a technology you know." His efforts to explore solutions were devoted primarily to going on visits to startups developing OpAccess technologies and conducting analyses showing the economic viability of the technology. Thus, Hugh's cognitive frame (pro-optical and pro-OpAccess) guided his data collection and analysis.

Actors were much more aware of the operation of other's frames than that of their own. According to Susannah (a member of the economic analysis team on the Last Mile project), "the technical team involved have only optical skills and background, so that being open to looking at the big access picture and other non-optical starting points wasn't going to be even considered." She implied that Hugh and his collaborators did not see the relevance of data that did not fit their frame. Reciprocally, Hugh observed about opponents to the Last Mile project, "If they find facts to support their view, they grab it at face value. Anything that 
contradicts their view, they put through a micro-fine sieve.” As these statements imply, individuals' cognitive frames affected their information gathering, analysis and interpretations. Such frames should not be understood simply as positions that an individual took regarding an initiative; to do so would neglect how the issues and scope for action were defined. The frame shaped the position, but it was not the position itself.

Because decisions require a matching between a problem and a solution, an actor's cognitive frame coupled diagnostic and prognostic aspects (Benford and Snow 2000; Campbell 2005). Diagnostic aspects of frames contributed to the participants' understanding of the problem: whether the crash in the optical market represented a threat or opportunity, or whether the market was experiencing a a radical shift in its trajectory or a temporary downturn. The managerial cognition literature's characterization of frames has focused almost exclusively on diagnostic frames, including: the environmental landscape (Gavetti and Levinthal 2000; Levinthal 1997), the nature of the technical change (Garud and Rappa 1994; Tripsas and Gavetti 2000), the competitive structure (Porac, Thomas and Baden-Fuller 1989; Sutcliffe and Huber 1998), and the degree of threat or opportunity (Gilbert and Bower 2002; Jackson and Dutton 1988). This literature has theorized less about the prognostic aspect of frames, though Garud and Rappa's (1994) analysis of scientists' different views for how the cochlear implant should be developed is an exception. The assumption has been that once managers make a diagnosis, they will know which solution to apply. However, it was clear from the unfolding of the Last Mile and Multiservice projects that disputes about views of the solution to the market challenges existed: what technology should be used; whether passion about the technology was an adequate criterion; or if formal decision-making procedures should trump other approaches.

Frames were not tools that actors could deploy at will. Observations at CommCorp suggest that an understanding of the sources of frames elucidates their effect in enabling and constraining an individual's scope of action. Previous research in managerial cognition has focused less on the origins of frames, though many scholars have suggested that demographic measures proxy cognitive features (Hambrick and Mason 1984; Wiersema and Bantel 1992). Implicit in demographic measures is the idea that different individual histories generate accumulations of knowledge that then lead to particular cognitive frames. Where such accumulations have been explored, it has been primarily in the research on thought worlds of functional 
groups such as R\&D or marketing (Dearborn and Simon 1958). These have been shown to lead to conflicts of interpretation (Bechky 2003; Carlile 2002; Dougherty 1992a), the resolution of which shape strategic issue definition and resource allocation (Glynn 2000). At CommCorp, I found that actors' frames were the products not only of their functional groups but also of the many other facets of their backgrounds.

It is therefore useful to conceptualize participants' frames as the encoding of a variety of previous experiences - including individual career histories, project experience, functional membership, position in the hierarchy - and contexts - including the firm, the industry and the prevailing technological paradigm. Each of these arenas had its own institutional logic that guided views and behavior (Thornton and Ocasio 1999) and contributed to a repertoire of institutional logics and knowledge accumulations (Bourdieu 1977; Gioia 1986; Zerubavel 1997). These frame repertoires functioned as tool kits from which actors constructed cognitive frames in responding to specific situations (Campbell 2005; Swidler 1986; Tarrow 1994). This understanding of frames has two implications: that actors could construct different frames in different contexts and that certain elements in repertoires could be shared within a firm by dint of common past experiences of individuals but could be enacted differently by each person (DiMaggio 1997). In addition, this multiplicity makes frames more fragile than typically portrayed in the managerial cognition literature and therefore a potential locus of contestation (Gamson 1985).

Table 2 shows how frames were made of systems of building blocks from actors' repertoires. These elements are portrayed in the table as pairs of contrasting views. Individual actors held these views to different degrees, but the descriptions usefully establish the main poles on the spectrum. The table also shows how these elements could be combined and recombined into different frames. For example, the "prooptical" frame clustered together views that the market downturn was temporary, that optics were the future of communications, that aggressive investment was needed in the short term and that "killer apps" were going to drive exponential market growth. The "business unit focus" frame included views about the need for ATG to reorient its priorities, about the value of market factors in technology investment decisions, about the value of business unit focus and about the importance of the formal decision-making processes.

-- Insert Table 2 here -- 
Based on career histories of each of the informants, I was able to trace the sources of accumulations presented in Table 2. Managers with optical training were likely to think that optics were the future of communications, that CommCorp should be investing in optics in the short term despite the market downturn and that lack of high-speed access to the end user was the limit to growth. Those with training in electronics and software were more likely to think that the optical market was saturated for a long time to come and that CommCorp should "move up the stack" from hardware to the application level of the system. CommCorp's norms about making all technologies in-house rather than outsourcing and about focusing on low-volume, high-value products were another source of accumulations. People with experience outside of CommCorp were more likely to value outsourcing and reorienting priorities away from the "Lab mindset" (in which research was valued over other functions). From these repertoires, CommCorp managers each evoked different cognitive frames to give meaning to the ambiguities they faced.

\section{Framing practices: constructing a predominant frame}

Such a view of frames suggests that actors held different frames but that change was possible. This opens up the prospect that actors can act purposefully to shape the frames of others in order to mobilize support for (or decrease the resistance to) a project (Benford and Snow 2000; Goffman 1974). Further, the stories of the Last Mile and Multiservice projects point out that the degree of congruence of an actor's cognitive frame with those of others (Orlikowski and Gash 1994) made engaging in framing practices more or less necessary. Such practices are situated performances (Feldman 2003; Orlikowski 2000) in which knowledgeable actors use their social skills to incite collective action (Bourdieu 1977; Fligstein 2001; Giddens 1984).

In the case of CommCorp, when frames about a particular initiative resonated widely in the organization, little opposition surfaced and no framing contest took place (as in the Multiservice project's initial decision to spin out a piece of the technology to support a business unit need). However, given the uncertainty faced by CommCorp, actors' frames were not often congruent, and no actor could impose his or her own frame on the decision-making process, at least not without contestation. Instead, proponents and opponents coalesced and then engaged in framing practices aimed at neutralizing opposition and building their own coalitions. Actors' interests were deeply implicated in this process. The framing practices of these 
coalitions aimed at mobilizing frames that were congruent with others' interests or caused others to see their interests in new ways. Each endeavor to shape the frames associated with a decision was met with counterframing efforts - those attempts to rebut, undermine or realign the diagnostic and prognostic frames held by the opposing coalition. How one frame came to predominate is akin to Weick's (1995: 6) notion of an implicit vote in the organization, but the evidence from this study shows that how people "voted" at any one point in time was influenced by the frames mobilized by coalitions engaged in these framing practices. The predominant frame was a practical accomplishment resulting from this purposeful action and interaction.

Figure 1 above shows that where initial frames are not congruent, actors are likely to engage in framing practices with the goal of achieving a degree of resonance that mobilized support for his or her own frame. At CommCorp, these framing practices were of two kinds: legitimacy battles and frame realignment. While the classification of these practices was derived inductively, the resulting categories were nicely congruent with the field-level concepts identified in the social movements literature (Benford and Snow 2000; Snow et al. 1986), and so I retain their terminology here. I found that these practices were an iterative means of working out which frame would meet the broadest set of interests in the organization. Table 3 gives examples of the types of framing practices undertaken by actors in the Last Mile and Multiservice projects.

-- Insert Table 3 here --

Legitimacy battles. Research on institutional change has emphasized the role of legitimating accounts and rhetoric as a means for individual actors and coalitions to reinforce their positions (Creed, Scully and Austin 2002; Zbaracki 1998). Evidence from the unfolding of the six decisions in the Last Mile and Multiservice projects suggests that legitimization work took various forms. Actors attempted to get their own frame to predominate through efforts both to establish the legitimacy of the frames - what Benford and Snow (2000: 620) call the "empirical credibility" of the frame - and to validate their own authority as claimsmakers (Lounsbury and Glynn 2001). In addition to reinforcing their own position, they also actively worked to undermine the legitimacy of the frames and authority of opposing coalitions.

The first recourse of proponents and opponents was to use data to bolster the legitimacy of their own frames or subvert that of others. Many studies of engineering cultures highlight the deep attachment of 
engineers to facts and rational analysis (Bucciarelli 1994; Kunda 1986; Vincenti 1990). Consistent with this view, managers at CommCorp noted that the company "is an engineering organization with engineering values and engineering analysis. You have to persuade people analytically." The battle most often began here: debating the empirical credibility of the frame. For example, Hugh used a 119-page PowerPoint document to initiate the Last Mile project. He argued that the optical market could rebound quickly if access technologies could increase end user demand (his diagnostic frame). This document framed the Last Mile project as, "Creating a demand for higher bandwidth services; providing a migration path towards a photonic-intensive network; providing demand to re-kindle growth of long-haul; enunciating a vision to coalesce a re-birth." While many opposed the project because they did not see a future in optics, they could not quickly counter the detailed evidence Hugh provided, so the Review Board approved an initial study.

After this, opponents of the project, mainly marketing team members such as Albert Lee and Susannah Watts, worked long hours late into the night for several weeks to provide a counter analysis showing, as Albert claimed in a meeting with the entire Last Mile team,

"The industry downturn and extremely tight CapEx [capital expenditures] and OpEx [operating expenditures] make it highly unlikely for service providers to deploy significant outside plant infrastructure in the near-term, and new fiber will be deployed only to those customers who can justify the expense on a case-by-case basis or in greenfield opportunities or in selected copper replacement areas...We would need to make the complete fiber story 100 times cheaper to be successful for this market...It's a copper based world for now, no backhoes."

"No backhoes" meant no new technologies such as fiber that would require the service providers to dig up the ground to install them. Hugh then launched an analysis of actual copper capabilities, and his PowerPoint document grew to 238 pages. His goal was to "beat down the doubting Thomases" with the force of the information provided. Consistent with Hugh's prognostic frame that OpAccess technologies were the appropriate solution to the market opportunity, his document also included a large section describing OpAccess approaches and each of the firms that were developing this kind of technology. Opponents to the project - primarily those in the marketing and economic analysis functions but also Theresa Veneto, the head of the Steering Committee - worked to show that OpAccess was only a niche solution.

According to Hugh, each side engaged in efforts to "debunk the debunkers" with further data and analysis. Much of what would be considered traditional strategy analyses such as opportunity identification 
was conducted as a part of these legitimacy battles. Actors' analyses were guided, however, by the particular frame that they brought to the situation. In the Multiservice project, Jack regularly referred to the "linear" thinking of the marketing team and of the business units. From his point of view, any analyses produced by marketers could not be trusted because they used the wrong assumptions about the market. The conclusion of these interactions was to gather more data to resolve these kinds of disputes, often with each side "dump trucking" data on the other. But, as Hugh suggested,

"Like most things, there is no absolute truth in anything. And, if you want to find the aspect to say it is a dog project, you can prove conclusively it's a dog. If you want to find the aspect to say, yeah, here are the golden nuggets that could make something really useful, you'll find it."

The empirical credibility battle often ended in impasse as the "facts" became malleable in the debates.

When data failed to build legitimacy for frames, proponents then turned to framing practices aimed at increasing their own legitimacy as claimsmakers or decreasing that of opponents. Such legitimacy can function as a cue to substitute for facts under conditions of ambiguity (Lounsbury and Glynn 2001). These efforts were essentially attempts to find a basis of power, through expertise, position, or reference to other influential actors or to cultural values (French and Raven 1968). Conscious of the need to manage the impressions of (Elsbach and Sutton 1992) and sell to (Dutton and Ashford 1993) more senior managers, proponents and opponents sought out legitimacy by lobbying Brad Copeland, the head of ATG, and other Review Board members in "backroom discussions." Each side attempted to call on important values within CommCorp, either old ones (e.g., Jack, as the leader of the Multiservice project, made regular reference to the role of ATG as the source of CommCorp's thought leadership) or new ones (e.g., the Last Mile marketing team insisted that CommCorp no longer placed primacy on optical technologies).

In both projects, consistent with the cultural values of an engineering organization, the project leaders advocated for the power of technical expertise. In the debate about OpAccess during the Last Mile project, Hugh argued that his long experience in access technology development - in contrast to those "who spell 'access' with a 'k'" (meaning, those who did not understand access technologies) - established his sole legitimacy in defining the investment decision. According to Vince Weston, an advisor to Brad Copeland, the discussions often became an "I-know-more-than-you debate." On the Multiservice project, Jack initially 
had convinced Brad about the opportunity. Yet, Tom Rentham found strong resistance from the business units who thought the technology was "threatening and cannibalizing." As a result, he could not support the project because he saw the world through a frame that valued a formal decision-making process and a solid business case. Tom's legitimacy as a claimsmaker came from his reliance on the power of the business units. So, despite Brad's enthusiasm for the technology, the business case frame won the day when the Steering Committee refused to review the project. But, Jack continued to rely on the tradition of technical expertise within ATG. He and other technology leaders refused to acknowledge the expertise of the marketing team in its own domain of market analysis.

Realigning frames. The projects often reached a final investment decision when one or the other side found a way to realign frames. At CommCorp, I observed the four types of frame alignment practices previously identified by Snow, Rochford, Worden and Benford (1986) - bridging, amplifying, extending and transforming (see examples in Table 3). Such efforts were aimed at changing the frame to mobilize the support of neutral actors or counteract the stance of opponents. This set of framing practices was essential to project outcomes but occurred alongside the legitimacy battles described above.

As an example, in the case of the Last Mile project, Hugh started out with a diagnostic frame based on a vision of CommCorp as a company that needed to live up to its "broadband birthright." He claimed that if CommCorp was going to stake its territory as a network company, then it needed to be in all parts of the network. He was able to overcome initial resistance by claiming that this project would only help CommCorp "get access to access" technologies rather than require the company to build the technology internally.

Facing further resistance, he amplified his claims to argue that it would be "an absolute competitive disaster" if CommCorp did not provide products to cover the last mile of the network. These tactics managed to gain enough support to assure agreement to fund an initial "100 days" of study.

This approach did not retain many adherents, despite Hugh's attempts to establish his own authority and the legitimacy of his frame. The head of the marketing team, Terrence Smith, said that his group was "circling the wagons" against the Last Mile proponents. The project was nearly shut down at the second decision point. Frustrated by his lack of ability to get his view to win, Hugh and his successor as project 
leader, Hermann, "staged a coup" by ceasing to communicate with the marketing team. They felt that the only way to move ahead was to reframe the project as one designed to support a business unit, and this guided a period of ultimately successful search for a willing internal partner. This new frame required them to narrow the scope of the project - including moving away from their frame of OpAccess as a solution - to be consistent with business unit needs. Opponents continued to push the "backhoe free" solution in an attempt to extend their business case frame to broader issues. However, by transforming the frame from one centered on OpAccess technologies as a response to a market threat to one in which access technologies would be responsive to business unit needs, Hugh and Hermann were able to deflect support away from the business case frame of their opponents. In those dire times, a business unit support frame resonated with most people and thus came to predominate when the final investment decision was made.

Similarly, Jack first attempted to frame Multiservice as necessary to meet the competitive threat coming from startups in this technical arena. This frame did not resonate broadly, so Jack got help from Edward Fischer (a senior technical colleague with years of experience in Silicon Valley) to reframe the project as something more palatable to the Steering Committee and Review Board. They felt that focusing on a particular customer need would be a more tangible way to view the market opportunity. By engaging a customer it a trial of the technology, the produced powerful evidence that a market opportunity existed. Edward also argued that this incremental step with a single customer was a phased means to implement what he hoped would ultimately be a more radical technology, thus bridging between a technology passion and business case frame. Theresa, as head of the Steering Committee, had long been an opponent, but her view was changed by these tactics. She noted after the project was formally approved:

"You'll be permitted [to invest] if you get a customer to say that their gut is saying this makes sense. So you are not standing alone, and it is tested enough with a few people. We will hedge it. I am willing to do a trial. But don't come to me alone, and say 'Believe in me, trust me."'

By framing the project as a phased effort, Jack extended the customer support frame to encompass Theresa's frame about the importance of using a formal decision-making process. Jack thus effectively increased the resonance of his own frame about the project and counteracted the arguments of the opposition.

The legitimacy and alignment framing practices tended to move in phases. In the Last Mile and 
Multiservice projects, the framing contests started with legitimacy battles over data supporting the frames. This was succeeded by battles over the legitimacy of the claimsmakers and eventually attempts to realign frames. While this study does not include enough cases to be able to sort out the contingencies which might provoke different sequences of framing practices, this order of activities seems consistent with evidence from the broader set of projects to which I was exposed during the field work and with a theoretical understanding of the relationship between these different practices. Given the engineering background of most of the actors in the ATG organization, it is not surprising that the contests started with the empirical credibility of the frame. Their natural instincts and training led them to focus on analysis first. Using data to sort definitively through differing views represents the idealized view of strategy making in which uncertainties can be resolved through the acquisition and analysis of additional information (Porter 1980). But, during this period of upheaval at CommCorp, it became clear that such analyses were not enough to get a particular frame to prevail over others, and actors turned their attention to substantiating their own legitimacy as claimsmakers.

This would suggest that efforts to fortify an actor's legitimacy would be observed when traditional analytical approaches failed. O'Keefe (1990) points out that attempts to establish legitimacy are only necessary when additional justification is needed to support a course of action. These legitimacy battles had the effect of defining positions and highlighting differences. This polarization made realigning frames easier because the points of contention were more clearly outlined. Frame realignment would be less likely to succeed if not preceded by the wrangling over the legitimacies of frames and claimsmakers. If realignment failed, then frames would continue to diverge, activities would remain unresolved and decisions would be deferred. This should not, however, be seen as a straightforward and linear process. In practice, the phases were quite iterative. Legitimacy battles often provoked new analysis of data. Realigning frames was primarily a search for alternative sources of legitimacy.

Frames and interests, framing and politics. The evidence presented here suggests that framing practices shaped and were shaped by the political pursuit of interests (as shown in Figure 2). Frames defined what was at stake (Bourdieu and Wacquant 1992), and the introduction of new frames was a means to transform interests. Interests were not fixed in the way conceived by rational choice models but rather were 
subject to interpretation. Actors would do what it took to motivate collective action, and in doing so they produced meaning for others and for themselves.

Much as individuals had a repertoire of knowledge accumulations that made it possible for different frames to be salient, they also had multiple, sometimes conflicting, interests, only some of which were relevant in a particular decision context. Some interests were tangible, such as getting a promotion or preserving one's job. Other interests were intangible, such as being seen as an expert, gaining peer recognition or working on "cool projects." Other interests had a collective aspect, such as a chance to contribute to the project team, support one's own functional group, or make ATG look good within CommCorp. Often interests were at odds with each other. When Hugh left the Last Mile decision meeting midstream, he was acting on his interest in being perceived as an expert but against his interest in preserving his position in the organization as he was subsequently removed as project leader.

The evidence suggests that interests cannot be seen as fixed properties of individuals. Which interests became salient depended on how actors framed the situation. Skilled social actors found frames that made others think that what was proposed was in their own interests (Fligstein 2001). A retelling of the Last Mile story could interpret the "pro-optical" stance as one of a self-interested desire to preserve jobs and maintain status. At the initiation of the project, ATG had just made a dramatic cut in another major optical project. As Albert Lee, a marketing team member, reflected later,

"The cynical view is that Last Mile got invented because there was nothing else for these [optical] people to do... They asked, 'what question can I construct to preserve my job, my people and my optical playground...' [But,] the other unsaid piece is that there is a hope that if we save more of the optical people and their expertise, the optical market will come back in a few years. The view is that we will need these people, and we will save the company, because we just completely believe in it. I will not say it is a religious thing, but it is a really intensely felt all-the-way-down-deep-in-the-soul type of thing that this is the right thing to do."

At first glance, this response would appear to be about raw interests alone: managers supported projects if the alternative might not include them and therefore put their jobs at risk. Yet, managers' perceptions of job alternatives were driven by their ability to envision alternative futures. In an era when layoffs were rife throughout CommCorp, managers would experience cognitive dissonance if their frames were inconsistent with individual or group interests. For example, resistance to the previous cuts in the optical program only diminished when the optical engineers saw that new projects, such as Multiservice or Last Mile, would 
provide other work opportunities. If ever a frame was mobilized that did not privilege interests of a critical mass of decision participants, the coalition then re-worked the issues to identify a combination of interests and frames that swayed the decision in their favor.

But, framing practices were not simply used by individuals making instrumental arguments to get their projects approved. Actors were not able to sell particular viewpoints unless these frames were present in their own frame repertoires. Framing was not just impression management but reflected the sensemaking of the actors. Framing was also aimed at getting the intended audience to see things differently. Therefore, one can conclude that the purposeful efforts at framing were intimately linked to both an actor's own sensemaking and that of others (as Fiss and Hirsch 2005, observed at the industry level). Selling could not happen absent the interpretation. For example, it was not until Edward Fischer joined the Multiservice project that realigning frames to focus on customer support was possible. Jack had continued to push the pure technology frame. Even after failing to get funding, he did not have the experience to reframe the project. Adding Edward and introducing the team to new frames (coming from Edward's Silicon Valley experience) had the effect of expanding the repertoires of the proposing team. Jack could never have won over either Tom or George with a "technology passion" frame because neither had a technical background and thus would not sympathize with such a view. Whereas, reframing the initiative as technical leadership for a customer bridged to their frames about the importance of responding to the market. The implication is that strategy making cannot be seen as driven purely by the political pursuit of interests. Because frames and interests are so tightly intertwined, political action is equally a means for promoting one's own frame for seeing investment choices. Predominant frames are thus practical accomplishments forged in contention.

\section{Summary}

Summing up the evidence on frames from the six decisions analyzed, I find that multiple frames about an investment choice existed, especially because of the turbulent present and uncertain future. As shown in Figure 2, the interactions of individuals in the form of framing contests shaped strategic outcomes. Such framing contests led to longer decision-making processes in the Last Mile and Multiservice projects than desired by the participants. Research in strategic management has suggested that fast decision speeds, in 
particular in turbulent environments, lead to better performance (Baum and Wally 2003; Eisenhardt 1989b). But, Brad Copeland, as the head of the ATG organization, felt that conflict was integral to the process. Just after Hugh stormed out of the decision meeting for the Last Mile project, Brad said,

"This is not easy. [The] Access [market] is catalytic to the success of the company. So, if there was an easy decision and no pushback, I would be very concerned. But, the fact that there is such emotion and such variety of opinion is a clear and positive indicator that this is an absolutely critical deliverable for the company. I would be worried if [the tension] were not there."

The plurality of frames and the presence of conflict appeared to be a vital part of strategy making in a setting with high stakes and ambiguous outcomes (Glynn et al. 2000). Framing contests were productive because they led to the vetting of ideas and balanced potential bias in decision-making. While it will be years before we know if the decisions to invest in Last Mile or Multiservice enhanced CommCorp performance, from the perspective of management, the conflictual decision-making process was essential.

Stepping back, the project-level framing contests analyzed in these two initiatives represent micromechanisms of a broader organizational shift in logics. The crash in the optics market presented a fundamental challenge to CommCorp. Where the "Lab mindset" had shaped the trajectories of action over many years, this path no longer appeared sustainable. These kinds of crises are critical moments for incumbent firms - adaptation is essential to survival. Ultimately, the frame that increasingly came to predominate in ATG decisions was one related to a business unit focus or customer-related opportunity. Slowly, the pursuit of "cool" new technologies lost its currency as a valid reason to invest. Institutional theorists have argued that during periods of upheaval, actors will put together alternative frames to organize activity (Fligstein 2001). This study provides a more granular perspective on how this change takes place. The framing contests model proposes that adaptation occurs not at the organizational level but rather at the project level in the day-to-day, often conflictual, interactions associated with choices about investment.

\section{DISCUSSION AND IMPLICATIONS}

This paper explores the role that cognitive frames played in shaping strategic choices during a period of high uncertainty in the case of two technology strategy projects. From this examination of the practices of strategy making, I have elaborated a model of framing contests which elucidates the ways that cognition and politics 
are linked. As with any ethnographic study, this exploration of CommCorp's strategy making is limited in its scope. It focused on one firm over the short period of eight months during the particularly extreme situation of a market crash. However, ATG's relatively democratic decision-making process, the high stakes nature of the decisions at hand, the uncertain market, and the accompanying widely diverging interpretations, likely made the framing contests I investigated especially dramatic. This period of upheaval brought out in relief dynamics that might be muted in more stable times (Meyer et al. 2005). I find that frames influence strategic choices, not in a deterministic fashion but rather in one mediated by organizational framing contests. This model opens up the black boxes of politics in cognitive models and of cognition in political models of strategy making by showing that frames are both constraints and resources for actors acting purposefully to shape strategic choices. These observations have implications for scholarship in managerial cognition and strategy making, in particular under conditions of uncertainty.

I have used social movements theories of framing (Benford 1993; Benford and Snow 2000) as an analytical lens through which to interpret the field data and develop a theory of framing contests in strategy making. I show that these ideas can be taken from the social policy domain and usefully applied to analyze processes within the firm. While the notion of using social movements theories to understand organizations' behaviors is not new, Zald (2005) has noted recently that these ideas have gained more traction in studying the role of organizations in shaping industry-level phenomena rather than in exploring dynamics inside organizations. By bringing social movements theory to bear in understanding the practices of managers making strategy at the project- and decision-levels of analysis, I can expose the conditions under which framing contests lead to predominant frames, or alternatively, lack of resolution and deferred decisions. This micro-level understanding extends social movement theories by taking into account the sources of frames and showing how frames change over time. Framing practices are not solely the instrumental or rhetorical acts to shape the frames of others described by social movements researchers but are also constrained and enabled by the frames through which each actor sees the world. Both the multiplicity of actors' frame repertoires as well as purposeful framing activities make shifts in frames possible. 


\section{Implications for understanding cognition and strategy}

This study responds to recent calls to move beyond content issues and investigate the processes that connect cognition to strategic outcomes (Bogner and Barr 2000), especially by looking at cognition as situated, interactive and temporally bounded (Elsbach et al. 2005; Lant 2002). In using frame analysis (Goffman 1974), I focus attention on the interrelationship between what is given (knowledge accumulations and frame repertoires) and what is constructed through interaction (predominant frames). The resulting practice-based framing contests model shows that predominant collective frames are not the mere aggregation of individual cognitions but rather a product of a dynamic process of meaning construction. Cognition is, therefore, not only contextually situated but also the outcome of political action. Framing is purposeful in the sense that individuals and groups engage in framing practices to shape the outcomes of investment decisions, and it is contested in the sense that the frames of different groups often come into conflict. This study demonstrates the inherently political nature of cognition in strategy making.

One implication is that the frames we observe empirically, particularly for quantitative studies, are static depictions that are an artifice required for analysis but do not capture the dynamics of the actual framing process. Any representation of a firm-level construct measuring cognition can only be understood as a negotiated outcome resulting from diverse internal views. This suggests that it is problematic to treat the firm as a macro-level whole in studies of strategy, in particular during periods of uncertainty. Rather than reifying the firm as an actor as much of the strategic management literature is wont to do, this work demonstrates the value of viewing it as a collective of people with different cognitive frames. And, as a result, firm response to change is a product of the interactions among them. The framing contests model sheds light on the organizational processes by which dominant logics emerge and change, something that has been of interest at both the field (Thornton and Ocasio 1999) and organizational levels (Prahalad and Bettis 1986). Goffman (1974: 25) calls to our attention what he calls the "embarrassing fact" that actors have

multiple frames, but such multiplicity does not have to be an inconvenient truth. It is precisely the polysemy of frame repertoires that make a change in logics possible. Framing practices, when skillfully deployed, can reshape frames such that new frames or logics triumph over old. 
Similarly, this portrayal of framing contests challenges the notion of a dominant coalition being a fixed entity in the organization. Framing practices can bring new coalitions to the fore and different coalitions may dominate in the context of different issues. Thus, framing contests are not just about senior managers engaging in the symbolic tasks of "sensemaking" and "sensegiving" to lower levels of the organization (Gioia and Chittipeddi 1991; Pfeffer 1981) nor about issue selling up the chain of command (Dutton and Ashford 1993). Different coalitions come to dominate in particular contexts through framing practices. All actors are potential producers and consumers of frames. And, while rhetorical strategies (Suddaby and Greenwood 2005; Zbaracki 1998) are clearly an essential tool for actors in these contests, they are part of a broader dynamic of negotiating meaning over time. A framing perspective differs by suggesting that frames are not only instrumental tools for the ex post justification of actions taken through power but rather are an ex ante part of the political process that produces decisions. Framing is not a set of symbolic actions distinct from substantive outcomes but instead a process by which these outcomes are constructed. Frames are the resources through which actors can gain influence. As a result, power can be accessible to multiple actors. Contesting frames is a way of changing the power structures in the organization.

These explorations offer one answer to the integration of cognitive and political models of strategy making and open up future avenues of study in managerial cognition. The evidence suggests that actors are more likely to see their own perspectives as objective and that of others as being biased by a frame which filters information. They see the operation of others' frames but not their own. Studies, perhaps even lab experiments, might explore the sources of this misattribution and also what conditions might provoke actors to be aware of their own frames. Further explorations might focus on examining how much difference in frames creates enough incongruence to trigger the use of framing practices (Orlikowski and Gash 1994). We also still need to know more about how individuals' different styles might predispose them to engage in particular framing practices and about the ways individuals deploy frames depending on the audience, the forum or other larger contextual issues (Creed, Langstraat and Scully, 2002). Comparative studies across organizations might also help develop a contingent model of the sequences of these framing practices. Such future research would further bolster our understanding of the micro-foundations of cognition in strategy. 


\section{Implications for models of strategy making}

Taking a practice approach to framing helps extend existing models of strategy making. While cognition has not been entirely absent from previous studies of strategic decision making, it was considered in a mainly behavioral, boundedly rational way in early models such as the "garbage can" (Cohen et al. 1972; March and

Olsen 1976). The framing contests model contains many echoes of the garbage can. Both models examine how solutions are matched with problems, but the garbage can obscures the actual decision-making process itself. The garbage can model objectifies problems and solutions: they do not change according to context. The framing contests model is differentiated in its focus on purposeful action to interpret problems and solutions and to catalyze a match between them. A practice-based framing perspective suggests that problems and solutions are actually subject to interpretation. Diagnostic frames shape the understanding of what the problem is, and prognostic frames guide views of the solution. The resolution of framing contests can shape which solutions match which problems. As others have noted, the garbage can model does not satisfactorily account for such purposeful action (Eisenhardt and Zbaracki 1992).

Subsequent studies of purposeful action in strategy processes have mainly foregrounded the political pursuit of interests (Bower 1970; Eisenhardt and Bourgeois 1988; Pettigrew 1973). The analysis in this paper suggests that the role of framing as a central mechanism within this process cannot be ignored. In the projects studied for this paper, many actors at different levels of the organization were relevant in making strategic choices, and groups of proponents and opponents coalesced to advance their own frames and interests. They engaged in framing practices to influence the decision. As a result, interests shaped ideas, but frames also created contexts for action, contexts which then reciprocally shaped the interests that participants came to have. In research on social movements, the turn towards framing was a corrective to political models which had failed to recognize that interests were not objectively given but rather defined and interpreted (Campbell 2005; McAdam, McCarthy and Zald 1996). Similarly, the framing contests model complements existing political models of strategy making by highlighting the essential role that frames play in shaping outcomes, such that framing practices and political action should be understood as tightly intertwined.

The appeal, therefore, of taking a practice approach to strategy making is that it helps conceptualize 
strategy makers as knowledgeable and purposive though not wholly free agents. This view admits more agency than assumed in behavioral theories but recognizes that such agency is not entirely unconstrained in the way imagined by strategic theories based on rational choice. It gives us analytical purchase to explore more complex manifestations of human agency, those in which actors are both constrained and enabled by their historically derived frame repertoires. It allows us to show that frames are not unified systems that drive outcomes in a consistent or determined direction. Instead, outcomes are mediated by the more or less skillful deployment of framing practices in organizational framing contests. A strategy-as-practice perspective distinguishes itself from its process theory antecedents in emphasizing the agency of individual actors, the situated nature of their action and an activity-level (rather than firm-level) of analysis (Jarzabkowski 2005; Johnson, Langley, Melin and Whittington 2007; Whittington 1996). As a result, we can push beyond simple "bounded rationality" (Simon 1947) notions of cognition in decision making or solely interest-based political models of strategic choice. The value of the practice approach is in challenging the structure of causality assumed in many traditional strategy models. It also shows how structures associated with interpretations of the environment and potential strategies of action are not fixed but rather constituted by particular actors in particular circumstances. The approach makes it possible to unpack the nature of human agency in these contexts, showing the potential for transformation as well as for routinization in action.

\section{Implications for understanding how firms manage change in the environment}

At the field level, institutional theorists are increasingly turning to explorations of the factors associated with emergence and change in addition to those that produce stability (c.f., Clemens and Cook 1999; Hirsch and Lounsbury 1997; Stryker 2000), and social movement theories figure prominently in these efforts (Lounsbury et al. 2003). Similarly, at the organizational level, the framing contests model could be extended to offer insights about the underlying dynamics of firm inertia and adaptation during periods of uncertainty. On the one hand, inertial responses can come from either the lock-in of an existing frame or the failure of a new one to prevail in the contest over meanings. In the case of successful incumbent organizations, it could be the case that a frame becomes deeply embedded the architecture of the organization (Henderson and Clark 1990). A predominant collective frame can be usefully seen as a "truce" (Nelson and Winter 1982) that 
embodies both a frame about what strategic direction should be pursued as well as a set of interests aligned with that frame (Kaplan and Henderson 2005). Organizations therefore might not be able to respond adequately to a change in the environment because an outmoded but institutionalized frame continues to predominate. Yet, the reproduction of a particular institutional set up is not always certain. A truce can break down if there is no longer a close fit with the external environment. Actors could then engage in framing practices in the pursuit of a new truce. Where alternative views do surface, the framing contests model suggests that organizations may still not be able to respond if a new frame does not come to prevail. In these cases, inertial responses will be the product of unresolved activities and deferred decisions.

On the other hand, the model also suggests that managers do not have to be victims of institutionalized frames. Adaptation can be the result of purposeful action on the part of actors to shape the frames of others. These efforts can lead new frames to predominate in new sets of strategic choices. Many firms have accomplished this is by replacing top managers (Tushman and Rosenkopf 1996; Virany, Tushman and Romanelli 1996) or by allowing autonomous decision making in various levels of the organization (Burgelman 1994). These efforts have the effect of changing or expanding the frame repertoires of management, thus enabling alternative frames to become salient. However, the framing contests model points out that change would also be possible through the entrepreneurial action of existing actors in the organization. Actors could choose to enact different frames by drawing differently on their frame repertoires and thus mobilizing action in a new direction. From a normative standpoint, this would suggest that managers might choose deliberately to promote framing contests in anticipation of or in early response to changes in the environment (Foster and Kaplan 2001; Schön and Rein 1994). Framing is a cognitive mechanism for change to the extent it affects how actors perceive the possibilities for such creative action.

\section{CONCLUSION}

The stories of the technology strategy decisions in the Last Mile and Multiservice projects provide insight into the mechanisms through which frames influence strategic choice. My field observations suggest a new understanding of framing in the context of turbulent environments. Information ambiguity is the linchpin of strategy making in periods of uncertainty, and framing is key to explaining how actors cope with it. The 
resolution of framing contests allows managers to move forward in the face of uncertainty. The empirical evidence from this study suggests that firms possess the makings of both adaptation and inertia. Strategic response is therefore constructed through the conflicts in frames and the purposeful action of managers seeking to make their own frames triumph over others. 


\section{REFERENCES}

Agar, M. 1980. The professional stranger : an informal introduction to ethnography. Academic Press, New York.

Agar, M. 1986. Speaking of ethnography. Sage Publications, Beverly Hills.

Allison, G.T. 1971. Essence of decision; explaining the Cuban missile crisis. Little Brown, Boston.

Archibald, K.A. 1970. Three views of the expert's role in policymaking. Policy Sciences 1 73-86.

Barnard, C.I. 1938. The functions of the executive. Harvard Univ. Press, Cambridge, Mass.,.

Barr, P.S. 1998. Adapting to unfamiliar environmental events: A look at the evolution of interpretation and its role in strategic change. Organization Science 9(6) 644-669.

Barr, P.S., J.L. Stimpert, A.S. Huff. 1992. Cognitive Change, Strategic Action, and Organizational Renewal. Strategic Management Journal 13(Special Issue) 15-36.

Baum, J.R., S. Wally. 2003. Strategic decision speed and firm performance. Strategic Management Journal 24(11) 1107-1129.

Bechky, B.A. 2003. Sharing meaning across occupational communities: The transformation of understanding on a production floor. Organization Science 14(3) 312.

Benford, R.D. 1993. Frame Disputes within the Nuclear Disarmament Movement. Social Forces 71(3) 677701.

Benford, R.D., D.A. Snow. 2000. Framing processes and social movements: An overview and assessment Annual Review of Sociology, Palo Alto, 611-639.

Bogner, W.C., P.S. Barr. 2000. Making sense in hypercompetitive environments: A cognitive explanation for the persistence of high velocity competition. Organization Science 11(2) 212-226.

Bolman, L.G., T.E. Deal. 1991/2003. Reframing organizations : artistry, choice, and leadership, 3rd ed. Jossey-Bass, San Francisco.

Bourdieu, P. 1977. Outline of a theory of practice. Cambridge University Press, Cambridge; New York.

Bourdieu, P., L.J.D. Wacquant. 1992. An invitation to reflexive sociology. University of Chicago Press, Chicago.

Bourgeois, L.J., III, K.M. Eisenhardt. 1988. Strategic Decision Processes in High Velocity Environments: Four Cases in the Microcomputer Industry. Management Science 34(7) 816-835.

Bower, J.L. 1970. Managing the resource allocation process: a study of corporate planning and investment, 2nd ed. HBS Press, Boston.

Bower, J.L., Y. Doz. 1979. Strategy Formulation: A Social and Political Process. D. Schendel, C. Hofer, eds. Strategic Management: A New View of Business Policy and Planning. Little Brown and Co., Boston.

Bucciarelli, L.L. 1994. Designing engineers. MIT Press, Cambridge, Mass.

Burgelman, R.A. 1983. A Process Model of Internal Corporate Venturing in the Diversified Major Firm. Administrative Science Quarterly 223.

Burgelman, R.A. 1994. Fading memories: A process theory of strategic business exit in dynamic environments. Administrative Science Quarterly 39(1) 24-56.

Campbell, J. 2005. Where do we stand? Common mechanisms in organizations and social movements research. G.F. Davis, D. McAdam, W.R. Scott, M.N. Zald, eds. Social movements and organization theory. Cambridge University Press, Cambridge ; New York, 41-68.

Carlile, P.R. 2002. A pragmatic view of knowledge and boundaries: Boundary objects in new product development. Organization Science 13(4) 442-455.

Child, J. 1972. Organization Structure and Strategies of Control - a Replication of the Aston Study. Administrative Science Quarterly 163.

Clemens, E.S., J.M. Cook. 1999. Politics and institutionalism: Explaining durability and change. Annual Review of Sociology 441-466. 
Cohen, M.D., J. March, G., J. Olsen. 1972. A garbage can model of organizational choice. Administrative Science Quarterly 17(1) 1.

Creed, W.E.D., J.A. Langstraat, M.A. Scully. 2002. A picture of the frame: Frame analysis as technique and as politics. Organizational Research Methods 34-55.

Creed, W.E.D., M.A. Scully, J.R. Austin. 2002. Clothes make the person? The tailoring of legitimating accounts and the social construction of identity. Organization Science 13(5) 475-496.

Daft, R.L., K.E. Weick. 1984. Toward a Model of Organizations as Interpretation Systems. Academy of Management Review 9(2) 284-295.

Davis, G.F., D. McAdam, W.R. Scott, M.N. Zald. 2005. Social movements and organization theory. Cambridge University Press, Cambridge; New York.

Dearborn, D.C., H.A. Simon. 1958. Selective Perception: A Note on the Departmental Identifications of Executives. Sociometry 21(2) 140-144.

Diesing, P. 1962. Reason in society; five types of decisions and their social conditions. University of Illinois Press, Urbana,.

DiMaggio, P.J. 1997. Culture and cognition. Annual Review of Sociology 23 263-287.

Dougherty, D. 1992a. Interpretive Barriers to successful product innovation in large firms. Organization Science 3(2) 179-202.

Dougherty, D. 1992b. A Practice-Centered Model of Organizational Renewal Through Product Innovation. Strategic Management Journal 13(Special Issue) 77.

Dougherty, D. 2002. Grounded theory building: some principles and practices. J.A.C. Baum, ed. Companion to Organizations. Blackwell Publishers, Oxford, UK, 849-867.

Dutton, J.E., S.J. Ashford. 1993. Selling issues to top management. Academy of Management Review 397424.

Eisenhardt, K.M. 1989a. Building Theories From Case Study Research. Academy of Management Review 532.

Eisenhardt, K.M. 1989b. Making Fast Strategic Decisions in High-Velocity Environments. Academy of Management Journal 32(3) 543-576.

Eisenhardt, K.M., L.J. Bourgeois, III. 1988. Politics of Strategic Decision Making in High-Velocity Environments: Toward a Midrange Theory. Academy of Management Journal 31(4) 737-770.

Eisenhardt, K.M., M.J. Zbaracki. 1992. Strategic decision making. Strategic Management Journal 13(Special Issue) 17.

Elsbach, K.D., P.S. Barr, A.B. Hargadon. 2005. Identifying Situated Cognition in Organizations. Organization Science 16(4) 422-433.

Elsbach, K.D., R.I. Sutton. 1992. Acquiring Organizational Legitimacy Through Illegitimate Actions: A Marriage of Institutional and Impression Management Theories. Academy of Management Journal 699736.

Feldman, M.S. 2003. A performative perspective on stability and change in organizational routines. Industrial And Corporate Change 12(4) 727-752.

Fine, G.A. 1993. The Sad Demise, Mysterious Disappearance, and Glorious Triumph of Symbolic Interactionism. Annual Review of Sociology 19 61-87.

Fiol, C.M., A.S. Huff. 1992. Maps for Managers: Where Are We? Where Do We Go from Here? Journal of Management Studies 29(3) 267-285.

Fiss, P.C., P.M. Hirsch. 2005. The Discourse of Globalization: Framing and Sensemaking of an Emerging Concept. American Sociological Review 70(1) 29-52.

Fligstein, N. 1996. Markets as politics: A political-cultural approach to market institutions. American Sociological Review 656.

Fligstein, N. 2001. Social skill and the theory of fields. Sociological Theory 19(2) 105-125. 
Foster, R.N., S. Kaplan. 2001. Creative Destruction: why companies that are built to last underperform the market -- and how to successfully transform them. Currency (Doubleday), New York.

French, J.R., Jr., B. Raven. 1968. The bases of social power. D. Cartwright, U. Zander, eds. Studies in social power. Institute for Social Research, Ann Arbor, Mich, 259-269.

Gamson, W.A. 1985. Goffman Legacy to Political-Sociology. Theory and Society 14(5) 605-622.

Gamson, W.A., D.S. Meyer. 1996. Framing political opportunity. D. McAdam, J.D. McCarthy, M.N. Zald, eds. Comparative perspectives on social movements: political opportunities, mobilizing structures, and cultural framings. Cambridge University Press, Cambridge England, 275-290.

Garud, R., M.A. Rappa. 1994. A socio-cognitive model of technology evolution: The case of cochlear implants. Organization Science 5(3) 344-362.

Gavetti, G., D. Levinthal. 2000. Looking forward and looking backward: Cognitive and experiential search. Administrative Science Quarterly 45(1) 113-137.

Giddens, A. 1984. The constitution of society : outline of the theory of structuration. University of California Press, Berkeley.

Gilbert, C., J.L. Bower. 2002. Disruptive change: When trying harder is part of the problem. Harvard Business Review 80(5) 94-101.

Gioia, D. 1986. Symbols, scripts and sensemaking: creating meaning in the organizational experience. H.P.J. Sims, D.A. Gioia, eds. The Thinking Organization. Jossey-Bass Publishers, San Francisco, 49-74.

Gioia, D.A., K. Chittipeddi. 1991. Sensemaking and Sensegiving in Strategic Change Initiation. Strategic Management Journal 12(6) 433.

Glynn, M.A. 2000. When cymbals become symbols: Conflict over organizational identity within a symphony orchestra. Organization Science 11(3) 285-298.

Glynn, M.A., P.S. Barr, M.T. Dacin. 2000. Pluralism and the problem of variety. Academy of Management Review 25(4) 726-734.

Goffman, E. 1974. Frame Analysis: An Essay on the Organization of Experience, 2nd (1986) ed. Northeastern University Press.

Goffman, E. 1983. The Interaction Order. American Sociological Review 48(1) 1-17.

Greenwood, R., C.R. Hinings. 1988. Organizational Design Types, Tracks and the Dynamics of Strategic Change. Organization Studies 9(3) 293-316.

Hambrick, D.C., P.A. Mason. 1984. Upper Echelons: The Organization as a Reflection of Its Top Managers. Academy of Management Review 9(2) 193-206.

Haveman, H.A. 1992. Between a Rock and a Hard Place: Organizational Change and Performance Under Conditions of Fundamental Environmental Transformation. Administrative Science Quarterly 37(1) 4876.

Henderson, R.M., K.B. Clark. 1990. Architectural Innovation: The Reconfiguration of Existing Product Technologies and the Failure of Established Firms. Administrative Science Quarterly 35(1) 9-30.

Hine, C. 2000. Virtual ethnography. Sage, London Thousand Oaks, Calif.

Hirsch, P.M., M. Lounsbury. 1997. Ending the family quarrel: Toward a reconciliation of "old" and "new" institutionalisms. The American Behavioral Scientist 40(4) 406-418.

Huff, A.S. 1990. Mapping strategic thought. John Wiley and Sons, Chichester, New York.

Jackson, S.E., J.E. Dutton. 1988. Discerning Threats and Opportunities. Administrative Science Quarterly 33(3) 370-387.

Jarzabkowski, P. 2005. Strategy As Practice: An Activity-Based Approach. Sage Publications, London.

Johnson, G., A. Langley, L. Melin, R. Whittington. 2007. Strategy as Practice: Research Directions and Resources. Cambridge University Press, Cambridge, UK. 
Johnston, H. 1995. A methodology for frame analysis: from discourse to cognitive schemata. H. Johnston, B. Klandermans, eds. Social Movements and Culture. University of Minnesota Press, Minneapolis, 217246.

Kaplan, S. Forthcoming. Cognition, capabilities and incentives: assessing firm response to the fiber-optic revolution. Academy of Management Journal.

Kaplan, S., R. Henderson. 2005. Inertia and incentives: bridging organizational economics and organizational theory. Organization Science 16(5) 509-521.

Kaplan, S., F. Murray, R.M. Henderson. 2003. Discontinuities and Senior Management: Assessing the Role of Recognition in Pharmaceutical Firm Response to Biotechnology. Industrial And Corporate Change 12(4) 203-233.

Kiesler, S., L. Sproull. 1982. Managerial Response to Changing Environments: Perspectives on Problem Sensing from Social Cognition. Administrative Science Quarterly 27(4) 548-570.

Knight, F.H. 1921/1965. Risk, uncertainty and profit. Harper \& Row, Publishers (first published in 1921 Hart, Schaffner \& Marx), New York.

Kunda, G. 1986. Engineering culture: culture and control in a high-tech organization.

Lant, T.K. 2002. Organizational cognition and interpretation. J.A.C. Baum, ed. Companion to Organizations. Blackwell Publishers, Malden, MA, 344-362.

Latour, B., S. Woolgar. 1979. Laboratory life: the construction of scientific facts, Orignally published Beverly Hills: Sage Publications, 1986 ed. Princeton University Press, Princeton, N.J.

Levinthal, D.A. 1997. Adaptation on rugged landscapes. Management Science 43(7) 934-950.

Lindblom, C.E. 1965. The intelligence of democracy; decision making through mutual adjustment. Free Press, New York,.

Louis, M.R. 1980. Surprise and Sense Making: What Newcomers Experience in Entering Unfamiliar Organizational Settings. Administrative Science Quarterly 25(2) 226-251.

Lounsbury, M., M.A. Glynn. 2001. Cultural entreprenuership: Stories, legitimacy, and the acquisitions of resources. Strategic Management Journal 22(6/7) 545-564.

Lounsbury, M., H. Rao. 2004. Sources of durability and change in market classifications: A study of the reconstitution of product categories in the American mutual fund industry, 1944-1985. Social Forces 82(3) 969-999.

Lounsbury, M., M.J. Ventresca, P.M. Hirsch. 2003. Social movements, field frames and industry emergence: a cultural-political perspective on US recycling. Socio-Economic Review 1(1) 71-104.

March, J.G. 1994. A Primer on Decision Making: How Decisions Happen. The Free Press, New York.

March, J.G., J.P. Olsen. 1976. Ambiguity and choice in organizations. Universitetsforlaget, Bergen.

McAdam, D., J.D. McCarthy, M.N. Zald. 1996. Introduction: Opportunities, mobilizing structures, and framing processes -- toward a synthetic comparative perspective on social movements. D. McAdam, J.D. McCarthy, M.N. Zald, eds. Comparative perspectives on social movements: political opportunities, mobilizing structures, and cultural framings. Cambridge University Press, Cambridge England New York, 1-20.

Meyer, A.D., V. Gaba, K.A. Colwell. 2005. Organizing Far from Equilibrium: Nonlinear Change in Organizational Fields. Organization Science 16(5) 456-473.

Nelson, R.R., S.G. Winter. 1982. An evolutionary theory of economic change. The Belknap Press of Harvard University Press, Cambridge, MA.

O'Keefe, D.J. 1990. Persuasion: theory and research. Sage Publications, Newbury Park, Calif.

Ocasio, W. 1997. Towards an attention-based view of the firm. Strategic Management Journal 18 187-206.

Orlikowski, W.J. 2000. Using technology and constituting structures: A practice lens for studying technology in organizations. Organization Science 11(4) 404-428.

Orlikowski, W.J., D.C. Gash. 1994. Technological Frames: Making Sense of Information Technology in Organizations. ACM Transactions on Information Systems 2(2) 174-207. 
Papadakis, V.M., S. Lioukas, D. Chambers. 1998. Strategic decision-making processes: The role of management and context. Strategic Management Journal 19(2) 115-147.

Pettigrew, A.M. 1973. The politics of organizational decision-making. Tavistock, London.

Pettigrew, A.M. 1987. Context and Action in the Transformation of the Firm. The Journal of Management Studies 24(6) 649.

Pfeffer, J. 1981. Power in organizations. Pitman Pub., Marshfield, Mass.

Porac, J.F., H. Thomas. 2002. Managing cognition and strategy: issues, trends and future directions. A.M. Pettigrew, H. Thomas, R. Whittington, eds. Handbook of strategy and management. Sage Publications, London Thousand Oaks, Calif., 165-181.

Porac, J.F., H. Thomas, C. Baden-Fuller. 1989. Competitive Groups as Cognitive Communities: The Case of Scottish Knitwear Manufacturers. Journal of Management Studies 26(4) 397-416.

Porter, M.E. 1980. Competitive strategy: techniques for analyzing industries and competitors. Free Press, New York.

Prahalad, C.K., R.A. Bettis. 1986. The Dominant Logic: A New Linkage Between Diversity and Performance. Strategic Management Journal 7(6) 485-501.

Rao, H. 1998. Caveat emptor: The construction of nonprofit consumer watchdog organizations. American Journal Of Sociology 103(4) 912-961.

Ryan, C. 1991. Prime time activism : media strategies for grassroots organizing, 1st ed. South End Press, Boston, MA.

Schön, D.A., M. Rein. 1994. Frame reflection: toward the resolution of intractable policy controversies. BasicBooks, New York.

Sewell, W.H. 1992. A Theory of Structure: Duality, Agency, and Transformation. The American Journal of Sociology 98(1) 1-29.

Simon, H.A. 1947. Administrative behavior; a study of decision-making processes in administrative organization. Macmillan Co., New York,

Smith, K.G., C.M. Grimm. 1987. Environmental Variation, Strategic Change and Firm Performance: A Study of Railroad Deregulation. Strategic Management Journal 8(4) 363.

Snow, D.A., E.B. Rochford Jr., S.K. Worden, R.D. Benford. 1986. Frame Alignment Processes, Micromobilization, and Movement Participation. American Sociological Review 51(August) 464-481.

Snow, D.A., S.A. Soule, H. Kriesi. 2004. The Blackwell companion to social movements. Blackwell Pub., Malden, MA.

Steinberg, M.W. 1999. The talk and back talk of collective action: A dialogic analysis of repertoires of discourse among nineteenth-century English cotton spinners. The American Journal of Sociology 105(3) 736-780.

Strauss, A.L., J.M. Corbin. 1997. Grounded theory in practice. Sage Publications, Thousand Oaks.

Stryker, R. 2000. Legitimacy processes as institutional politics: implications for theory and research in the sociology of organizations Research in the Sociology of Organizations. JAI Press, Amsterdam, 179-223.

Suddaby, R., R. Greenwood. 2005. Rhetorical strategies of legitimacy. Administrative Science Quarterly 50(1) 35-67.

Sutcliffe, K.M., G.P. Huber. 1998. Firm and industry as determinants of executive perceptions of the environment. Strategic Management Journal 19(8) 793-807.

Swidler, A. 1986. Culture in Action: Symbols and Strategies. American Sociological Review 51(2) 273.

Szulanski, G., Y. Doz, Y. Ovetzky. 2004. Incumbents' framing: Three established companies respond to the internet. Advances in Strategic Management: Business Strategy Over the Industry Life Cycle 21 77-106.

Tarrow, S.G. 1994. Power in movement : social movements, collective action, and politics. Cambridge University Press, Cambridge England New York. 
Thornton, P.H., W. Ocasio. 1999. Institutional logics and the historical contingency of power in organizations: Executive succession in the higher education publishing industry, 1958-1990. AMERICAN Journal Of Sociology 105(3) 801-843.

Tripsas, M., G. Gavetti. 2000. Capabilities, cognition, and inertia: Evidence from digital imaging. Strategic Management Journal 21(10/11) 1147-1161.

Tushman, M.L., L. Rosenkopf. 1996. Executive succession, strategic reorientation and performance growth: A longitudinal study in the U.S. cement industry. Management Science 42(7) 939-953.

Tversky, A., E. Shafir. 1992. Choice under conflict: The dynamics of deferred decision. Psychological Science 3(6) 358.

Vincenti, W.G. 1990. What engineers know and how they know it : analytical studies from aeronautical history. Johns Hopkins University Press, Baltimore.

Virany, B., M.L. Tushman, E. Romanelli. 1996. Executive Succession and Organization Outcomes in Turbulent Environments. W.M. Cohen, L. Sproull, eds. Organizational learning. Sage Publications, Thousand Oaks, Ca.

Walsh, J.P. 1995. Managerial and organizational cognition: Notes from a trip down memory lane. Organization Science 6(3) 280-321.

Weick, K.E. 1995. Sensemaking in organizations. Sage Publications, Thousand Oaks.

Weick, K.E., K.M. Sutcliffe, D. Obstfeld. 2005. Organizing and the Process of Sensemaking. Organization Science 16(4) 409-421.

Whittington, R. 1996. Strategy as practice. Long Range Planning 29(5) 731-735.

Wiersema, M.F., K.A. Bantel. 1992. Top Management Team Demography and Corporate Strategic Change. Academy of Management Journal 35(1) 91-121.

Yin, R.K. 1984. Case study research: design and methods. Sage Publications, Beverly Hills, Calif.

Zald, M.N. 2005. The Strange Career of an Idea and its Resurrection: Social Movements in Organizations. Journal of Management Inquiry 14(2) 157-166.

Zald, M.N., M.A. Berger. 1978. Social-Movements in Organizations - Coup D'Etat, Insurgency, and Mass Movements. American Journal Of Sociology 83(4) 823-861.

Zbaracki, M.J. 1998. The rhetoric and reality of total quality management. Administrative Science Quarterly 602-636.

Zerubavel, E. 1997. Social mindscapes: an invitation to cognitive sociology. Harvard University Press, Cambridge, Mass. 
Figure 1: Framing Contests

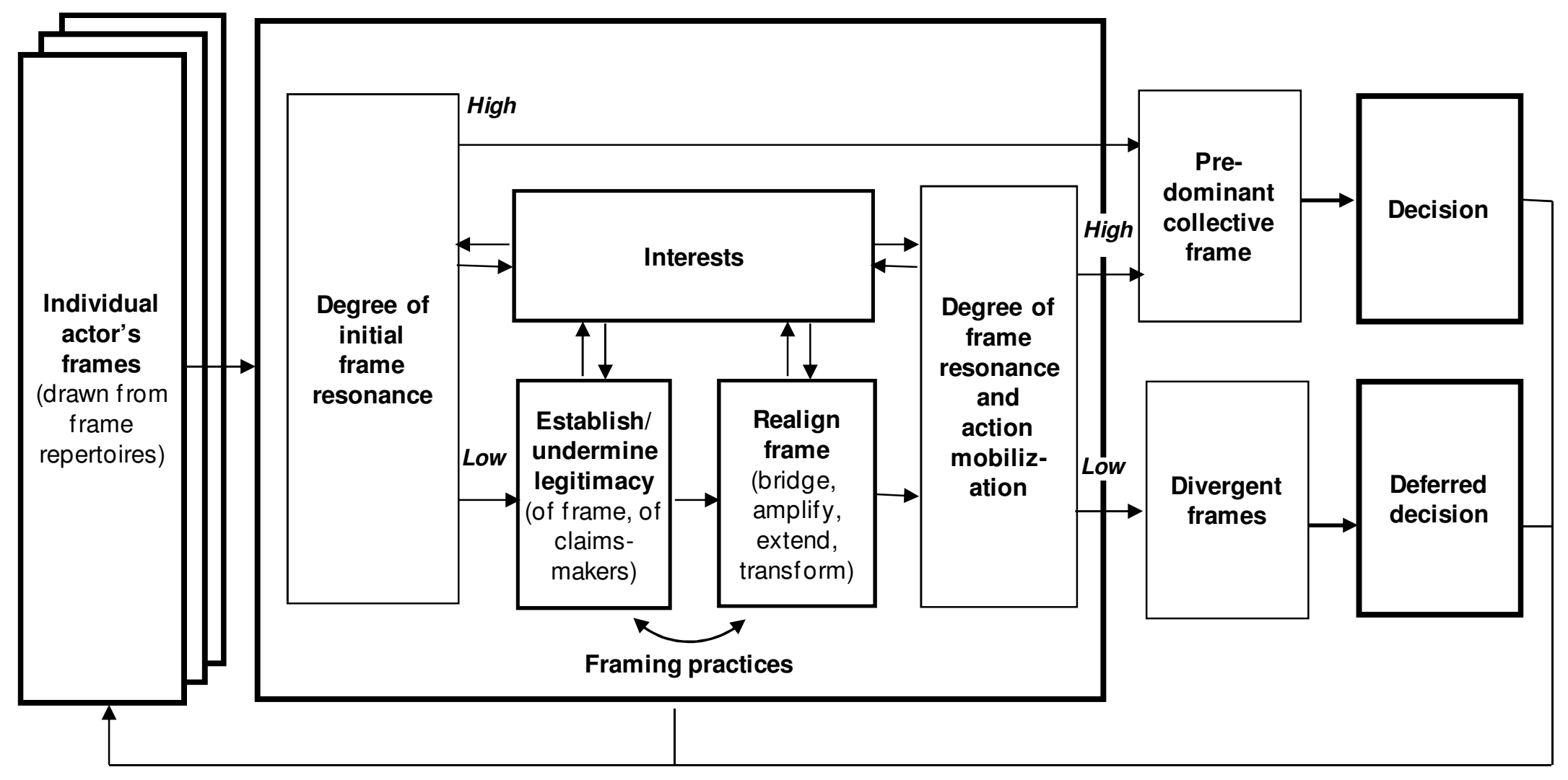




\section{Table 1: Projects, Decisions, Frames and Coalitions}

\begin{tabular}{|c|c|c|c|c|c|c|c|c|c|}
\hline \multirow{3}{*}{$\begin{array}{l}\text { Unit of } \\
\text { observation: } \\
\text { the project }\end{array}$} & \multirow{3}{*}{$\begin{array}{l}\text { Unit of analysis: } \\
\text { pivotal decisions } \\
\text { (resource allocation decisions) }\end{array}$} & \multirow{3}{*}{$\begin{array}{l}\text { Con- } \\
\text { tested }\end{array}$} & \multirow[b]{3}{*}{ Decision } & \multicolumn{3}{|c|}{ Proponents/supporters } & \multicolumn{3}{|c|}{ Opponents } \\
\hline & & & & Main members & Fra & es & Main members of & & nes \\
\hline & & & & of coalition & Diagnostic & Prognostic & coalition & Diagnostic & Prognostic \\
\hline \multirow{3}{*}{$\begin{array}{l}\text { "Last Mile": } \\
\text { Large project } \\
\text { to identify } \\
\text { market and } \\
\text { technical } \\
\text { opportunity in } \\
\text { access } \\
\text { technologies }\end{array}$} & $\begin{array}{l}\text { Decision } 1 \text { (June): Choice to } \\
\text { initiate major exploration } \\
\text { project in new market }\end{array}$ & Yes & Decision & - Hugh $\left({ }^{*} \dagger T\right)$ & $\begin{array}{c}\text { Pro-optical } \\
\text { (market threat) }\end{array}$ & Pro-OpAccess & - Susannah (M/B) & Anti-optical & Anti-OpAccess \\
\hline & $\begin{array}{l}\text { Decision } 2 \text { (July): "Non- } \\
\text { decision." Final decision } \\
\text { postponed but agreed to } \\
\text { continue investing in project for } \\
\text { another month }\end{array}$ & Yes & $\begin{array}{l}\text { Deferred } \\
\text { decision }\end{array}$ & $\begin{array}{l}\text { - Hugh }\left({ }^{*} T \mathrm{~T}\right) \\
\text { - Hermann }\left({ }^{*} \mathrm{~T}\right) \\
\text { - Edward }\left({ }^{*} \mathrm{~T}\right)\end{array}$ & $\begin{array}{l}\text { Market } \\
\text { opportunity }\end{array}$ & $\begin{array}{l}\text { Pro-OpAccess } \\
\text { Technology } \\
\text { passion }\end{array}$ & $\begin{array}{l}\text { - Susannah }(M / B) \\
\text { - } \text { Albert }(M / B) \\
\text { - Theresa }\left(\dagger^{\star} T\right) \\
\text { - Terrence }\left(\dagger^{M} / B\right) \\
\text { - } \operatorname{Max}\left(\dagger^{M} M / B\right) \\
\text { - Erik }\left(\dagger^{*} T\right)\end{array}$ & $\begin{array}{c}\text { Market } \\
\text { pessimism }\end{array}$ & Business case \\
\hline & $\begin{array}{l}\text { Decision } 3 \text { (September): } \\
\text { Decision to narrow focus to a } \\
\text { particular application area, for a } \\
\text { specific business unit }\end{array}$ & Yes & Decision & $\begin{array}{l}\text { - Hugh }\left({ }^{*} T \mathrm{~T}\right) \\
\text { - Hermann }\left({ }^{*} \mathrm{~T}\right) \\
\text { - Jack }\left({ }^{*} \mathrm{~T}\right) \\
\text { - Brad }(\dagger) \\
\text { - Albert }(\mathrm{M} / \mathrm{B}) \\
\text { - Edward }\left({ }^{*} \mathrm{~T}\right) \\
\end{array}$ & $\begin{array}{c}\text { Market } \\
\text { opportunity }\end{array}$ & $\begin{array}{l}\text { Business unit } \\
\text { focus }\end{array}$ & $\begin{array}{l}\text { - Susannah }(\mathrm{M} / \mathrm{B}) \\
\text { - Theresa }\left(\dagger^{\star} \mathrm{T}\right)\end{array}$ & $\begin{array}{c}\text { Market } \\
\text { pessimism }\end{array}$ & Business case \\
\hline \multirow{3}{*}{$\begin{array}{l}\text { "Multiservice": } \\
\text { Effort to } \\
\text { introduce a } \\
\text { protocol } \\
\text { technology } \\
\text { that would } \\
\text { allow service } \\
\text { providers to } \\
\text { offer multiple } \\
\text { services to } \\
\text { their } \\
\text { customers } \\
\text { without them } \\
\text { having to } \\
\text { scrap legacy } \\
\text { equipment }\end{array}$} & $\begin{array}{l}\text { Decision } 1 \text { (June): Uncontested } \\
\text { decision to invest in developing } \\
\text { a specific function as an } \\
\text { incremental improvement for a } \\
\text { specific product line }\end{array}$ & No & Decision & $\begin{array}{l}\text { - Jack }\left({ }^{*} \mathrm{~T}\right) \\
\text { - } \operatorname{Tom}\left({ }^{*} \mathrm{M} / \mathrm{B}\right) \\
\text { - } \operatorname{Brad}(\mathrm{\dagger})\end{array}$ & $\begin{array}{c}\text { Market } \\
\text { opportunity }\end{array}$ & $\begin{array}{l}\text { Business unit } \\
\text { focus }\end{array}$ & - NA & $\begin{array}{l}\text { NA (not } \\
\text { contested) }\end{array}$ & $\begin{array}{l}\text { NA (not } \\
\text { contested) }\end{array}$ \\
\hline & $\begin{array}{l}\text { Decision } 2 \text { (July): "Non- } \\
\text { decision." Project not passed to } \\
\text { Review Board due to lack of } \\
\text { business case. Results in not } \\
\text { funding project. }\end{array}$ & Yes & $\begin{array}{l}\text { Deferred } \\
\text { decision }\end{array}$ & $\begin{array}{l}\text { - Jack }\left({ }^{*} T\right) \\
\text { - } \operatorname{Brad}(\dagger)\end{array}$ & $\begin{array}{c}\text { Pro-optical } \\
\text { (market threat) }\end{array}$ & $\begin{array}{l}\text { Technology } \\
\text { passion }\end{array}$ & $\begin{array}{l}\text { - } \text { Tom }\left({ }^{*} \mathrm{M} / \mathrm{B}\right) \\
\text { - George }\left({ }^{*} \mathrm{M} / \mathrm{B}\right) \\
\text { - Theresa }\left(\dagger^{\star} \mathrm{T}\right) \\
\text { - Chris }(\dagger \mathrm{M} / \mathrm{B}) \\
\text { - Josh }\left({ }^{*} T\right)\end{array}$ & Anti-optical & $\begin{array}{l}\text { Business unit } \\
\text { focus } \\
\text { Formal } \\
\text { process }\end{array}$ \\
\hline & $\begin{array}{l}\text { Decision } 3 \text { (August/ } \\
\text { November): Informal decision } \\
\text { to dedicate substantial } \\
\text { resources to develop the } \\
\text { technology (later ratified by } \\
\text { Steering Committee) }\end{array}$ & Yes & Decision & $\begin{array}{l}\text { - Jack }\left({ }^{*} T\right) \\
\left.\text { - Edward }{ }^{*} \mathrm{~T}\right) \\
\text { - Erik }\left(\dagger^{*} \mathrm{~T}\right) \\
\text { - } \operatorname{Brad}(\dagger)\end{array}$ & $\begin{array}{c}\text { Market } \\
\text { opportunity }\end{array}$ & $\begin{array}{l}\text { Customer } \\
\text { orientation } \\
\text { Technology } \\
\text { passion }\end{array}$ & - George ( $\left.{ }^{*} \mathrm{M} / \mathrm{B}\right)$ & $\begin{array}{c}\text { Market } \\
\text { pessimism }\end{array}$ & $\begin{array}{l}\text { Formal } \\
\text { process }\end{array}$ \\
\hline
\end{tabular}

$\dagger \quad$ Member of Review Board

Member of Steering Committee

$T$ Technical function

M/B Marketing or business function 
Table 2: Frame Repertoires and Frames for Last Mile and Multiservice Initiatives

\begin{tabular}{|c|c|c|c|c|c|c|c|c|c|c|c|c|c|c|c|c|c|c|c|c|c|}
\hline \multicolumn{10}{|c|}{ Sources of accumulations } & \multirow[t]{2}{*}{ Representative elements in repertoire } & \multicolumn{4}{|c|}{$\begin{array}{c}\text { Diagnostic } \\
\text { aspects of } \\
\text { frames }\end{array}$} & \multicolumn{7}{|c|}{$\begin{array}{l}\text { Prognostic } \\
\text { aspects of } \\
\text { frames }\end{array}$} \\
\hline \multirow[t]{4}{*}{ 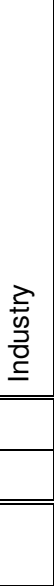 } & 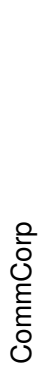 & 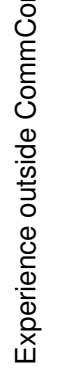 & $\stackrel{0}{\stackrel{0}{e}}$ & 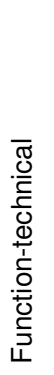 & 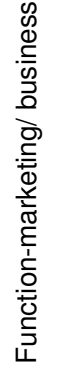 & 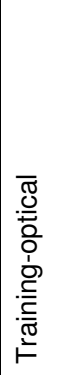 & 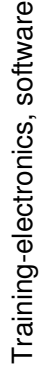 & 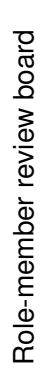 & 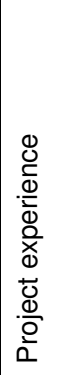 & & 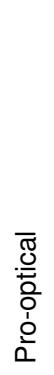 & 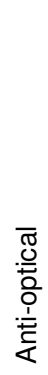 & 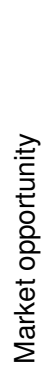 & 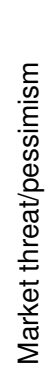 & 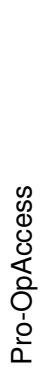 & 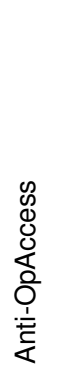 & 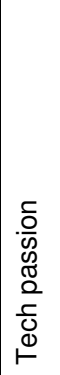 & 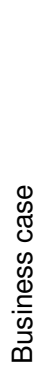 & 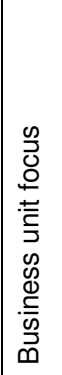 & 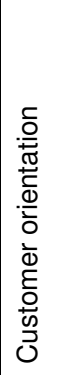 & 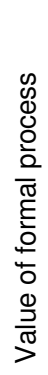 \\
\hline & & & & $\sqrt{ }$ & & & & & & Optimistic about the market ("the downturn is temporary") - OR - & & & $\sqrt{ }$ & & & & & & & & \\
\hline & $\sqrt{ }$ & & & & $\sqrt{ }$ & & & & & Pessimistic about the market ("the downturn changes the market trajectory") & & & & $\sqrt{ }$ & & & & & & & \\
\hline & & & & & & $\sqrt{ }$ & & & & $\begin{array}{l}\text { "Access is the current rate limiter" to market growth. Find hardware solutions } \\
\text { to access and you will fix the market slump - OR - }\end{array}$ & & & $\sqrt{ }$ & & & & & & & & \\
\hline \multirow[t]{4}{*}{$\sqrt{ }$} & & $\sqrt{ }$ & & & & & $\sqrt{ }$ & & & $\begin{array}{l}\text { Hardware level ("Level 0/1") is saturated. Need to "move up the stack" to } \\
\text { applications and services }\end{array}$ & & & & $\sqrt{ }$ & & & & & & & \\
\hline & & $\sqrt{ }$ & & $\sqrt{ }$ & & & & & & "Killer apps" will drive exponential demand growth - OR - & & & $\sqrt{ }$ & & & & & & & & \\
\hline & & & & & $\sqrt{ }$ & & & & & "No killer apps foreseeable"; flat or slow demand growth & & & & $\sqrt{ }$ & & & & & & & \\
\hline & & & & & & $\sqrt{ }$ & & & $\sqrt{ }$ & Optics are the technology for the "future of communications" - OR - & $\sqrt{ }$ & & & & & & & & & & \\
\hline \multirow[t]{2}{*}{$\sqrt{ }$} & $\sqrt{ }$ & & & & $\sqrt{ }$ & & $\sqrt{ }$ & & & The optical market is "saturated" for a long time to come & & $\sqrt{ }$ & & & & & & & & & \\
\hline & & & & $\sqrt{ }$ & & $\sqrt{ }$ & & & & $\begin{array}{l}\text { Need to continue aggressive development of optical technologies to "be ready } \\
\text { when the market comes back" - OR - }\end{array}$ & $\sqrt{ }$ & & & & & & & & & & \\
\hline \multirow[t]{9}{*}{$\sqrt{ }$} & & & & & $\sqrt{ }$ & & $\sqrt{ }$ & & & $\begin{array}{l}\text { Can minimize investment in optical technology development because the } \\
\text { "market doesn't justify investment" }\end{array}$ & & $\sqrt{ }$ & & & & & & & & & \\
\hline & & & & & & $\sqrt{ }$ & & & & $\begin{array}{l}\text { CommCorp should continue to focus on longhaul and optical; "optical is the } \\
\text { advanced technology" in communications - OR - }\end{array}$ & $\sqrt{ }$ & & & & & & & & & & \\
\hline & & $\sqrt{ }$ & & & & & $\sqrt{ }$ & & & CommCorp should focus on new technical arenas ("beyond optical") & & $\sqrt{ }$ & & & & & & & & & \\
\hline & & & & & & & & & $\sqrt{ }$ & CommCorp can manage "high volume/low cost" businesses - OR - & & & & & $\sqrt{ }$ & & & & & & \\
\hline & $\sqrt{ }$ & & & & $\sqrt{ }$ & & & & & CommCorp should make low volume/high value products ("core competence") & & & & & & $\sqrt{ }$ & & & & & \\
\hline & $\sqrt{ }$ & & $\sqrt{ }$ & & & & & & & CommCorp should "make in-house" a total communications solution - OR - & & & & & $\sqrt{ }$ & & & & & & \\
\hline & & $\sqrt{ }$ & & & $\sqrt{ }$ & & & & & CommCorp should focus on a few high value areas and "outsource" the rest & & & & & & $\sqrt{ }$ & & $\sqrt{ }$ & & & \\
\hline & & & & $\sqrt{ }$ & & & & & & $\begin{array}{l}\text { Marketing and business unit people are "linear thinkers;" technical people } \\
\text { understand the market potential better (they are the "experts") - OR - }\end{array}$ & & & & & $\sqrt{ }$ & & $\sqrt{ }$ & & & & \\
\hline & & & & & $\sqrt{ }$ & & & & & Technical people get "obsessed with own technologies," don't factor in market & & & & & & $\sqrt{ }$ & & $\sqrt{ }$ & & & $\sqrt{ }$ \\
\hline
\end{tabular}




\begin{tabular}{|c|c|c|c|c|c|c|c|c|c|c|c|c|c|c|c|c|c|c|c|c|c|c|}
\hline \multicolumn{10}{|c|}{ Sources of accumulations } & \multirow[t]{2}{*}{ Representative elements in repertoire } & \multicolumn{4}{|c|}{$\begin{array}{l}\text { Diagnostic } \\
\text { aspects of } \\
\text { frames }\end{array}$} & \multicolumn{8}{|c|}{$\begin{array}{c}\text { Prognostic } \\
\text { aspects of } \\
\text { frames }\end{array}$} \\
\hline 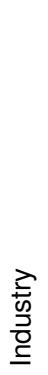 & $\begin{array}{l}\text { 음 } \\
\text { రิ } \\
\text { है } \\
\text { ठ }\end{array}$ & 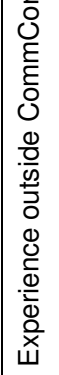 & $\stackrel{\text { c }}{\stackrel{4}{<}}$ & 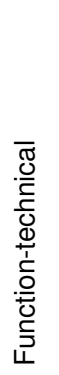 & 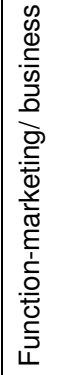 & 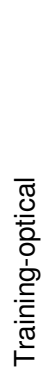 & 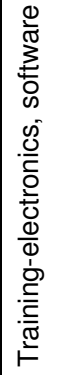 & 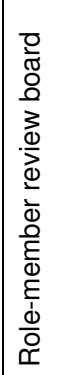 & 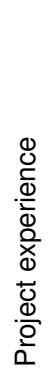 & & 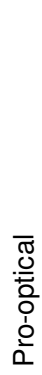 & 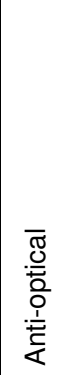 & 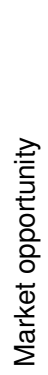 & 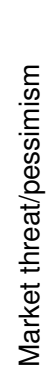 & 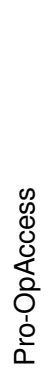 & 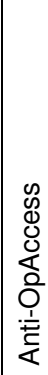 & 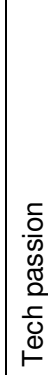 & & 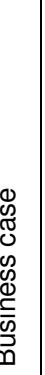 & 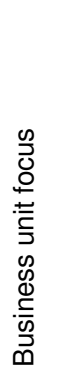 & 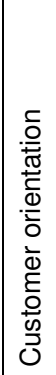 & 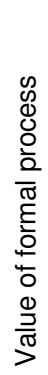 \\
\hline & & & & $\sqrt{ }$ & & & & & & Carriers will invest in new infrastructure if it "protects revenue streams" - OR & & & & & $\sqrt{ }$ & & & & & & & \\
\hline$\sqrt{ }$ & & & & & $\sqrt{ }$ & & & & & Carriers won't invest in new infrastructure (only "backhoe free" solutions) & & & & & & $\sqrt{ }$ & & & & & $\sqrt{ }$ & \\
\hline & & & & & & & & & $\sqrt{ }$ & OpAccess technology is comprehensive solution to access market - OR - & & & & & $\sqrt{ }$ & & & & & & & \\
\hline & & & & & $\sqrt{ }$ & & & & & OpAccess technologies have at best some niche applications & & & & & & $\sqrt{ }$ & & & & & & \\
\hline & & & $\sqrt{ }$ & $\sqrt{ }$ & & & & & & $\begin{array}{l}\text { ATG should be an industry technical leader ("respond to all competitive } \\
\text { threats" to leadership) - OR - }\end{array}$ & & & & & & & $\sqrt{ }$ & & & & & \\
\hline & $\sqrt{ }$ & $\sqrt{ }$ & & & $\sqrt{ }$ & & & $\sqrt{ }$ & & ATG needs to reorient priorities given change in market (no "Lab mindset") & & & & & & & & & $\sqrt{ }$ & $\sqrt{ }$ & $\sqrt{ }$ & \\
\hline & & & & $\sqrt{ }$ & & & & & & "Passion" for an idea may win in decision making - OR - & & & & & & & $\sqrt{ }$ & & & & & \\
\hline & & & & & $\sqrt{ }$ & & & $\sqrt{ }$ & & "Rigorous analysis" is essential (industry crisis due to faulty industry analysis) & & & & & & & & & & & & $\sqrt{ }$ \\
\hline & & & & $\sqrt{ }$ & & & & & & $\begin{array}{l}\text { Technology driven factors should predominate in decisions (we should be } \\
\text { building "cool stuff") - OR - }\end{array}$ & & & & & & & $\sqrt{ }$ & & & & & \\
\hline & & & & & $\sqrt{ }$ & & & & & Market/"business factors" should predominate in decisions & & & & & & & & & $\sqrt{ }$ & $\sqrt{ }$ & $\sqrt{ }$ & \\
\hline & & & & $\sqrt{ }$ & & & & & & $\begin{array}{l}\text { ATG needs to "think ahead of the business units," develop technologies even } \\
\text { if the business is not supportive (long term technology development) - OR - }\end{array}$ & & & & & & & $\sqrt{ }$ & & & & & \\
\hline & & & & & $\sqrt{ }$ & & & $\sqrt{ }$ & & $\begin{array}{l}\text { ATG shouldn't do anything that doesn't have "business unit focus" (need short } \\
\text { term cash flow orientation) }\end{array}$ & & & & & & & & & & $\sqrt{ }$ & & \\
\hline & & & $\sqrt{ }$ & $\sqrt{ }$ & & & & & & CommCorp should invest to remain a "technology leader" - OR - & & & & & & & $\sqrt{ }$ & & & & & \\
\hline & $\sqrt{ }$ & $\sqrt{ }$ & & & $\sqrt{ }$ & & & & & CommCorp should be more "customer facing" & & & & & & & & & & & $\sqrt{ }$ & \\
\hline & & & & $\sqrt{ }$ & & & & & & Get funding where you can; circumvent the formal process if you can - OR - & & & & & & & $\sqrt{ }$ & & & & & \\
\hline & & & & & $\sqrt{ }$ & & & $\sqrt{ }$ & & $\begin{array}{l}\text { All projects should meet "Steering Committee criteria," be vetted through the } \\
\text { formal decision-making process }\end{array}$ & & & & & & & & & & & & $\sqrt{ }$ \\
\hline & & & & $\sqrt{ }$ & & & & & & The push to develop business cases "erodes creativity" - OR - & & & & & & & $\sqrt{ }$ & & & & & \\
\hline & & $\sqrt{ }$ & & & $\sqrt{ }$ & & & $\sqrt{ }$ & & The "business case" is essential to justify funding a project & & & & & & & & & $\sqrt{ }$ & & & $\sqrt{ }$ \\
\hline
\end{tabular}


Table 3: Framing Practices Used in Last Mile and Multiservice Initiatives

\begin{tabular}{|c|c|c|c|}
\hline & \multicolumn{2}{|c|}{ Establish or challenge the legitimacy... } & \multirow[t]{2}{*}{ Align frames } \\
\hline & $\ldots$ of the frame & $\ldots$ of the claimsmaker & \\
\hline Last Mile & $\begin{array}{l}\text { - Hugh's } 119 \text { (eventually 238) } \\
\text { page PowerPoint document } \\
\text { - Response from technical team } \\
\text { to marketing team: "We think } \\
\text { you did good work but we don't } \\
\text { believe it." } \\
\text { - Do the copper analysis to } \\
\text { "debunk the debunkers" } \\
\text { - Marketing team "circles the } \\
\text { wagons" to make sure that } \\
\text { individual analyses can't be } \\
\text { picked apart } \\
\text { - Edward launches effort to } \\
\text { gather more data on "killer } \\
\text { apps" that will drive nonlinear } \\
\text { demand increases (after Albert } \\
\text { argues that he can't find any } \\
\text { data on killer apps) }\end{array}$ & $\begin{array}{l}\text { - Claim that those "who spell } \\
\text { 'access' with a 'k"' should not } \\
\text { have a claim to influence } \\
\text { decisions } \\
\text { - Marketing team argues that } \\
\text { industry no longer values optics } \\
\text { - Susannah holds numerous } \\
\text { "backroom discussions" with } \\
\text { Theresa to force the project } \\
\text { through the Steering Committee } \\
\text { process } \\
\text { - Hugh walks out of review } \\
\text { meeting } \\
\text { - Hugh argues that it is the } \\
\text { customers who demand an end } \\
\text { to end solution } \\
\text { - Hermann and Hugh "stage a } \\
\text { coup" to seek out support from } \\
\text { business unit }\end{array}$ & $\begin{array}{l}\text { - Bridging: Hugh claims that he is } \\
\text { only doing a study to get "access to } \\
\text { access" (rather than building the } \\
\text { technology internally) } \\
\text { - Amplifying: Hugh's switch in } \\
\text { description of project from } \\
\text { "broadband birthright" to "absolute } \\
\text { competitive disaster" not to have a } \\
\text { presence in access } \\
\text { - Extending: Marketing team focuses } \\
\text { on requiring a "backhoe free" } \\
\text { solution } \\
\text { - Transforming. Hugh and Hermann } \\
\text { move from a "pro-OpAccess" frame } \\
\text { to arguing that the project will be } \\
\text { essential in order to support the } \\
\text { needs of a particular business unit }\end{array}$ \\
\hline Multiservice & $\begin{array}{l}\text { - Jack's initial detailed analysis of } \\
\text { Multiservice technologies } \\
\text { - When Jack wants the business } \\
\text { case revisited, George refuses } \\
\text { because he has done the } \\
\text { analysis once and feels that he } \\
\text { is being bullied by Jack } \\
\text { - Jack argues that marketing } \\
\text { team uses "linear" thinking and } \\
\text { therefore the numbers are not } \\
\text { representative of the real } \\
\text { opportunity } \\
\text { - Jack eventually puts some } \\
\text { numbers together to support the } \\
\text { case }\end{array}$ & $\begin{array}{l}\text { - Jack and Edward identify a } \\
\text { customer (a service provider) to } \\
\text { support the project } \\
\text { - Jack argues that technical } \\
\text { expertise should dominate } \\
\text { marketing views (as it had in the } \\
\text { old days) } \\
\text { - Jack makes continual reference } \\
\text { to the role of ATG as a technical } \\
\text { leader } \\
\text { - Theresa gets Jack's boss (Erik) } \\
\text { to insist the project follow the } \\
\text { Steering Committee process } \\
\text { - Tom argues that he cannot } \\
\text { identify any business unit to } \\
\text { support the project }\end{array}$ & $\begin{array}{l}\text { - Transforming: When the "market } \\
\text { optimism" frame doesn't resonate, } \\
\text { Jack makes early attempt to sell } \\
\text { project as a response to } \\
\text { competitive threat } \\
\text { - Amplifying: Later shift from } \\
\text { competitive threat to customer need } \\
\text { - Extending: Proponents argue that } \\
\text { the project is and "exploratory" trial } \\
\text { for a customer so that approval } \\
\text { makes sense because a business } \\
\text { case could eventually emerge from } \\
\text { these explorations } \\
\text { - Bridging: Edward reframes project } \\
\text { as radical technology but with } \\
\text { implementable incremental steps }\end{array}$ \\
\hline
\end{tabular}




\section{Appendix 1: Coding Cognitive Frames}

(example from Hermann Meier, proponent of Last Mile project)

\begin{tabular}{ll}
\hline $\begin{array}{l}\text { Decision } \\
\text { context }\end{array}$ & Evidence of frame (diagnostic) \\
\hline Decision 1 & $\begin{array}{l}\text { Pro-optical } \\
\text { - }\end{array}$ \\
& "A very large number of buildings for medium and \\
& small enterprise were not being picked off. So we \\
& shifted from tall, shiny buildings [to a focus on \\
& access to smaller users]." [Interview 6/10] \\
- & "We are sort of 'access refugees' because \\
& CommCorp had actually canceled its whole \\
& access program about a year and half ago." \\
& [Interview 6/10] \\
- & "We can calculate the size of the application for \\
& optics. There are enough cases to make the \\
& opportunity interesting." [Hallway discussion with \\
& Hugh and Vince, 6/19]
\end{tabular}

\section{Decision 2 Market opportunity}

- Albert: The gist of what I have presented is that the "build it and they are going to come and pay for it' view is completely discredited. Theresa: We can't be the farm on the potential for a killer app. Hermann: This is good work, but maybe we should have a what if scenario if the killer app does happen. [Last Mile team meeting, 8/8]

- "There has been 75\% growth in DSL. Yet, [marketing people show] the demand side having zero potential, or that carriers have already reached that potential. It is hard to reconcile these numbers. And, the demand side analysis was based on a single carrier to reach the saturation conclusion. But, why would people participate in [an access standards body] if the potential were filled? The overall implications of Albert's results are too conservative even for the carriers. We are overreacting [to the market downturn]: this is the analyst reaction, it's all about the flavor of the month." [Interview 8/9]

\section{Decision 3 Market opportunity}

- "Approx $40 \%$ of those SME's with dial-up today are looking to migrate to broadband as they make the internet mission critical." [email to Last Mile team 8/15]

- "We have directed the majority of the Last Mile effort based on historical trends. You are pointing out the potential danger of looking in the rear-view mirror. Fair enough. I still want the project's focus to be on the limitations and capabilities of copper, and the complementary use of fiber." [email to Albert Lee, 8/15]

- "If somebody was very definitive [at the Review Board meeting] that the market was not going to get bigger for the foreseeable future, I would have said, this is a Bill Gatesism, you know, $64 \mathrm{~kb}$ of RAM is not enough for anybody." [Interview 9/19]

\section{Business unit focus}

- "We went off line, we staged a coup. It is not that we didn't want to work with these [marketing] people, but we needed to clear the air and have a focused technical session with the business unit." [Interview 9/19]

- "The proposal was business unit oriented, the effort proposed was not huge, at the low ball end of the spectrum, and it deepens the linkage into a line of business." [Interview 9/19]

- "[With regard to business unit focus], I wanted something that was clean, and new, and opportunistic. You know that would lead us into a different relationship. We will build and evolve the relationship. Last Mile is just beyond where they are currently thinking. So it is very complementary." [Interview 9/19] 